\title{
CROATIAN PEASANT PARTY IN ITALY FROM 1945 TO 1947
}

\author{
Ivan TEPE $\check{S}^{*}$
}

\begin{abstract}
The aim of this paper is to present and analyse the hitherto poorly researched activities of the Croatian Peasant Party (CPP) in Italy from June 1945 to mid-1947, based on archival sources of the Yugoslav Secret Service, CPP emigrant media and relevant literature. This is a period that marks the arrival and departure of prominent CPP members from Italy. The paper analyses the mutual relationship of CPP members in the party and their attitude towards other emigrant groups and Croatian refugees. During the observed period, most of the CPP's pre-war MPs who found themselves in exile resided in Italy, and Italy was then one of the most important party centres of activity.
\end{abstract}

Keywords: Croatian Peasant Party, Italy, Yugoslavia, Croatian political diaspora, refugee camps

\section{Introduction}

Previous scientific research into the activities of the Croatian political diaspora in the first post-war years was largely devoted to the fates of members of the Ustasha movement and their leader Ante Pavelić. In the case of the CPP in exile, research focused on the activities of CPP President Vladko Maček, and the activities of the pre-war CPP MPs and prominent CPP members who found themselves in exile were secondary. ${ }^{1}$ Therefore, for a better understand-

\footnotetext{
* Ivan Tepeš, Ph. D., Croatian Heritage Foundation, Zagreb, Croatia

1 Amy Schmidt, "Vladko Maček i Hrvatska seljačka stranka: Prizori iz izbjeglištva" ["Vladko Maček and The Croatian Peasant Party: Scenes from Exile"], Časopis za suvremenu povijest 37 (2005), No. 3: 407-422.; Branka Boban, "Vladko Maček u emigraciji - od izlaska iz zemlje do odlaska u SAD" ["Vladko Maček in exile - from leaving the country to going to the USA"], Radovi Zavoda za hrvatsku povijest Filozofskog fakulteta Sveučilišta u Zagrebu 39(2007), No.
} 
ing and elucidation of this part of Croatian history, it is important to analyse the activities of politicians who were very important and prominent in the prewar period, and who found themselves in exile after the war. The paper mostly uses the fund of the State Security Service in the Croatian State Archive in Zagreb for the reconstruction of their activities, which contains data obtained from service associates who were among the emigrants, and information obtained by the Yugoslav Secret Service during 1947 and 1948 at hearings of high-ranking and lower-ranking Ustasha officials extradited to Yugoslavia and those arrested in Yugoslavia as part of Operation "Gvardijan". ${ }^{3}$ Some of the information can be found in the letters of the priest Krunoslav Draganović written at the time, as well as in his testimony before the Yugoslav investigative bodies in 1967, after he returned to Yugoslavia. ${ }^{4}$ Data on the activities of CPP members in Italy from 1945 to 1947 can also be found in published

1: 243- 258.; Bogdan Krizman, Pavelić u bjekstvu [Pavelić on the run] (Zagreb: Globus, 1986.); Berislav Jandrić, "Saveznički izbjeglički logori počeci otpora hrvatske političke emigracije komunističkom režimu u domovini/logor Fermo/" ["Allied refugee camps beginnings of resistance of Croatian political diaspora to the communist regime in the homeland / Fermo camp"], in: 1945. - razdjelnica hrvatske povijesti: Zbornik radova sa znanstvenog skupa održanog u Hrvatskom institutu za povijest od 5. do 6. svibnja 2005., ed. Nada Kisić Kolanović, Mario Jareb and Katarina Spehnjak (Zagreb: Hrvatski institut za povijest, 2006.), pp. 305-322. Bernd Robionek, Croatian Political Refugees and the Western Allies: A documented History (Berlin: Osteuropa - Zentrum Berlin, 2010); Hrvoje Petrić, "Prilozi za biografiju Ivana Pernara (1889.1967.)" ["Contributions to the biography of Ivan Pernar (1889.-1967.)“], Zbornik Janković 2 (2017), N o. 2: 197-204.; Hrvoje Petrić, "Prilozi za biografiju hrvatskog političara Josipa Torbara" ["Contributions to the biography of Croatian politician Josip Torbar"], Zbornik Jankovic 3 (2018), No. 3: 193-196.; Ivan Tepeš, Hrvatska politička emigracija - HSS [Croatian political diaspora - CPP] (Zagreb: AGM d.o.o., 2021.)

2 "Gvardijan" was the name of an operation by the Yugoslav secret service that lasted from July 1947 to July 1948, during which participants in the "April 10" operation, led by Božo Kavran, were arrested. Members of Kavran's group, beginning in June 1947, moved from abroad to Yugoslavia with the aim of re-establishing the NDH, but the Yugoslav secret service captured all participants from the beginning, most of whom were sentenced to death, including Kavran. See more: Zdenko Radelić, Križari: Gerila u Hrvatskoj 1945. - 1950. [Crusaders: Guerrillas in Croatia 1945-1950] (Zagreb: Alfa d.d. i Hrvatski institut za povijest, 2011.), pp. 143-153.

3 Hrvatski državni arhiv (HDA) [Croatian State Archives], fond [Record Group] 1561, Služba državne sigurnosti Ministarstva unutrašnjih poslova Socijalističke Republike Hrvatske (SDS RSUP SRH) [State Security Service of the Ministry of the Interior of the Socialist Republic of Croatia] (Record Group's Signature: HR-HDA-1561)

4 Jere Jareb, “Dr. Krunoslav Draganović o svojem radu u Italiji, od rujna 1943. do ožujka 1946.” [Dr. Krunoslav Draganović on his work in Italy, from September 1943 to March 1946], Hrvatska revija (München-Barcelona), 34 (1984), No. 4: 589 - 611.; HR-HDA-1561, 010.24, "Odlazak dr Mačeka i nekih prvaka Hrvatske seljačke stranke iz Zagreba, uoči ulaska jedinica Jugoslavenske narodne armije" ["Departure of Dr. Maček and some leaders of the Croatian Peasant Party from Zagreb, before the entry of Yugoslav People's Army units”], November 5, 1967. 
memoirs and letters of emigrants who resided in Italy ${ }^{5}$ at the time and in the CPP emigrant official gazette Croatian Voice (Hrvatski glas).

In the 1930s, the CPP reached its peak, especially after the 1938 elections and the creation of the Banovina of Croatia in August 1939, to have its officials divided into three groups during World War II. One part remained on Maček's line of passivity towards Ustasha power in the Independent State of Croatia (Nezavisna Država Hrvatska; NDH), the other part joined the Ustasha movement and took high positions within it, and the third part sided with the partisan movement. ${ }^{6}$ After the end of the war, one part of the CPP officials went into exile, and among them was President Vladko Maček. General Secretary Juraj Krnjević had been in exile since April 1941, when he left Yugoslavia with the Yugoslav government. This paper focuses on the activities of those pre-war MPs and prominent officials who operated within the CPP in Italy from 1945 to 1947.

CPP officials left Zagreb on May 6, 1945, in a group that included members of the NDH Government. Among the pre-war CPP deputies in that group were Josip Torbar with his sons, Ivan Pernar with his wife, Josip Reberski with his wife and two children, Ante Budimirović and Ivan Čelan. ${ }^{7}$ On the same day, Vladko Maček also left Zagreb, independently of other CPP officials. ${ }^{8}$ In

\footnotetext{
5 Ivo Rojnica, Susreti i doživljaji [Encounters and Experiences] (Zagreb: DoNeHa, 1994.), p. 110.; Ernest Bauer, Život je kratak san [Life is a short dream] (Barcelona-München: Knjižnica Hrvatske revije, 1986.), pp. 304-305.; Milivoj Mostovac, "Idejno izbjeglištvo: Rim 1945-47" [“Ideologically exile: Rome 1945-47”], Hrvatska revija - Jubilarni zbornik 1951 - 1975, ed. Vinko Nikolić (München-Barcelona: Knjižnica Hrvatske revije , 1976), pp. 372-379.; Vinko Nikolić, Tragedija se dogodila u svibnju [The Tragedy occurrred in May], vol. 2 (Zagreb: Školske novine, 1995.), p. 113.; Ivo Lendić, Božji kotači [God’s wheels] (Split: Laus d.o.o., 2001).
}

6 Read more about the activities of the CPP during World War II: Fikreta Jelić-Butić, $\mathrm{Hr}$ vatska seljačka stranka [Croatian Peasant Party] (Zagreb: Globus, 1983.); Zdenko Radelić, Hrvatska seljačka stranka 1941. - 1950. [Croatian Peasant Party 1941 - 1950] (Zagreb: Hrvatski institut za povijest, 1996.)

Andrej Maček, Nino Škrabe, (eds), Maček izbliza [Maček up close] (Zagreb: Disput, 1999.), p. 114..; Tepeš, Hrvatska politička emigracija - HSS, p. 45.; Krizman, Pavelić u bjekstvu, pp. 27-28.; Radelić, Hrvatska seljačka stranka 1941. - 1950., p. 39.; A part of the prominent CPP members who emigrated were released from the prison in Lepoglava half a month earlier, where the Ustasha authorities imprisoned them in late August 1944 after the collapse of the "Lorković-Vokić coup". Branko M. Pešelj, "S predsjednikom Mačkom u emigraciju" ["With President Maček in Exile”], in: Hrvatska revija 20(1970), No. 4., pp. 758-762. Ivan Čelan (1890. - 1968.) was a pre-war representative of the CPP, but with the establishment of the NDH he joined the Ustasha movement and was appointed deputy head of the movement.

8 Vladko Maček, Memoari [Memoirs] (Zagreb: Hrvatska seljačka stranka, 1992.), pp. 177178.; Pešelj, "S predsjednikom Mačkom u emigraciju”, pp. 763-766.; HR-HDA-1561, No. 301839-1, Dosje Vladko Maček [Dossier Vladko Maček], 132.; Boban, "Vladko Maček u emigraciji - od izlaska iz zemlje do odlaska u SAD”, 246.; Maček, Škrabe, Maček izbliza, p.114.; 
the last three days before leaving Zagreb, Pernar, Torbar, Reberski, Božidar Vučković, and some other prominent CPP members, held talks with Maček and most likely made their decision to leave in consultation with him, fearing the communists and convinced that they would have the help of Western democratic countries to return. ${ }^{9}$ Maček was stationed in Paris until August 1947, while the other CPP deputies stayed in Austria for several months before arriving in Italy.

\section{The arrival of the first group of CPP members in Rome and the establishment of the "Zagreb Canteen"}

The first groups of Croatian post-war refugees from Austria began arriving in Italy in June $1945 .{ }^{10}$ There were better living conditions in Italy, and Rome was more attractive because of the possibility of influencing international factors through numerous diplomatic missions in that city. In addition, Croats, as Catholics, counted on the maximum assistance of Catholic institutions from Rome and the Vatican. ${ }^{11}$

Budimirović was the first of the pre-war CPP deputies to arrive in Rome from Austria in June with a small group of people. ${ }^{12}$ Budimirović immediately connected with the famous painter Jozo Kljaković, who had his own studio on the second floor of the Institute of St. Jerome, and through Kljaković he connected with Juraj Mađerac, the Rector of the Institute. ${ }^{13}$ Budimirović

Jere Jareb, Zlato i novac NDH izneseni u inozemstvo 1944. $i$ 1945. [Gold and money of the Independent State of Croatia exported abroad in 1944 and 1945] (Zagreb: Hrvatski institut za povijest - Dom i svijet, 1997.), pp. 294., 350.; Danijel Crljen, Otvoreno pismo dru Vladku Mačeku, predsjedniku Hrvatske seljačke stranke [An open letter to Dr. Vladko Maček, President of the Croatian Peasant Party] (Buenos Aires: writer's edition, 1948.), p. 37.; ROJNICA, Susreti i doživljaji, 255.; Tepeš, Hrvatska politička emigracija - HSS, 45.

9 For more details on the meetings and Maček's reasons for leaving the country, see: Tepeš, Hrvatska politička emigracija - HSS, pp. 41-45.

10 Jandrić, "Saveznički izbjeglički logori počeci otpora hrvatske političke emigracije komunističkom režimu u domovini/logor Fermo”, p. 313.

11 Jandrić, "Saveznički izbjeglički logori počeci otpora hrvatske političke emigracije komunističkom režimu u domovini/logor Fermo”, p. 313.

12 HR-HDA-1561, 1.9/3, "Hrvatski odbor u Rimu" ["The Croatian Committee in Rome], August 1948, p. 16.; Jandrić, "Saveznički izbjeglički logori počeci otpora hrvatske političke emigracije komunističkom režimu u domovini/logor Fermo", p. 313.

13 HR-HDA-1561, 1.9/3, "Hrvatski odbor u Rimu”, August 1948, p. 16.; HR-HDA-1561, 1.9/3, "O skrivanju zločinaca po samostanima i sv. Jeronimu” ["About hiding criminals in monasteries and St. Jerome"], August 1948, p. 2. 
was accommodated on the first floor of the Institute, and in the Institute he met Fr. Dominik Mandić, who was then working in the Vatican as the main economist of the Franciscan Order. He also connected with a very influential Croatian priest and secretary of the Brotherhood of St. Jerome ${ }^{14}$ Krunoslav Draganović, with whom he had known before. ${ }^{15}$ With the help of these priests, he founded a kitchen called "Zagreb Canteen", ${ }^{16}$ which, with the approval of Rector Mađerac, was located on the first floor of the Institute. ${ }^{17}$ Along with Budimirović, the kitchen was established by CPP pre-war deputies Ivan Čelan and Stipe Matijevici ${ }^{18}$ with the aim of providing their own food and with their own financial expenses, but with the arrival of larger groups of emigrants in Rome, the kitchen expanded and a committee was established to take care of its supply. ${ }^{19}$ The official founding of the Zagreb canteen with Budimirović as president dates back to around July 15, 1945, and the first regular assembly was held on August 4, 1945. ${ }^{20}$ The establishment of the canteen was reported to the Italian state authorities, from whom it received a license to operate. All members of the canteen paid 70 lire per day for two meals, and it was difficult for those refugees who came to Rome without any material means to pay, ${ }^{21}$ so already in the first days a third of the meals were not charged. During the first 19 days of operation, 781 meals were issued, of which 502 were charged, 58 were with debt, 126 were free, and 95 were for people passing through Rome. ${ }^{22}$ The increase in activities due to the increased flow of refugees also increased the costs of maintaining the canteen, which could not be financed only by wealthier emigrants, but support was sought from Mađerac, Mandić and Draganović, and the issue was resolved primarily with Mandić's

14 The Brotherhood of St. Jerome was founded within the Institute of St. Jerome on July 19, 1945, and the founding assembly was attended by members of the CPP Kljaković, Šutej and Šuljak. (Andrija Lukinović, "Bratovština svetog Jeronima za pomoć hrvatskim izbjeglicama" ["The Brotherhood of St. Jerome to help Croatian refugees"], in: Papinski hrvatski zavod svetog Jeronima (1901-2001): Zbornik u prigodi stoljetnice Papinskoga hrvatskog zavoda svetog Jeronima, ed. Jure Bogdan (Rome, Italy: Papinski hrvatski zavod svetog Jeronima and Glas Koncila, 2001.), p. 785.

15 HR-HDA-1561, 1.9/3, “Hrvatski odbor u Rimu”, August 1948, p. 16.

16 Ibidem.

17 Andrija Lukinović, "Bratovština svetog Jeronima za pomoć hrvatskim izbjeglicama”, p. 821

18 Stipe Matijević (1887. - 1972.) was a pre-war representative of the CPP who joined the Ustasha movement with the establishment of the NDH and was appointed deputy head of the movement.

19 HR-HDA-1561, 1.9/3, "Hrvatski odbor u Rimu", August 1948, p. 16

20 Lukinović, "Bratovština svetog Jeronima za pomoć hrvatskim izbjeglicama”, p. 821

21 HR-HDA-1561, 1.9/3, "Hrvatski odbor u Rimu”, August 1948, p. 16

22 Lukinović, "Bratovština svetog Jeronima za pomoć hrvatskim izbjeglicama”, pp. 821-822. 
financial assistance..$^{23}$ Assistance to refugees was distributed regularly, and the supply of groceries to the canteen was provided from the Vatican's supply warehouses at the best price, provided that they were occasionally provided free of charge. At the same time, foodstuffs were taken from the supply warehouse of the municipal administration of the city of Rome through tickets for the refugees from the area of Rome. ${ }^{24}$ According to the testimonies of some emigrants, the meals in the canteen were tasty and plentiful, ${ }^{25}$ but for some they were expensive because they did not have any material resources, so they depended on the good will of the "boss" Budimirović. ${ }^{26}$ Everyone could get food in the canteen, regardless of party affiliation and activities during the war, ${ }^{27}$ although in the first months it used to happen that some Ustasha emigrants were rejected. ${ }^{28}$ In addition to food, the canteen premises were used for short-term accommodation and reception of refugees, who were then sent to other destinations. ${ }^{29}$ The work of the canteen developed widely already in late 1945 and early 1946, and was known among emigrants, bringing together

23 HR-HDA-1561, 1.9/3, "Hrvatski odbor u Rimu", August 1948, p. 16

24 Ibidem.

25 HR-HDA-1561, 1.9/3, "Hrvatski odbor u Rimu”, August 1948, p. 16; Bauer, Život je kratak san, 305.; Rojnica, Susreti i doživljaji, p. 110

26 Bauer, Život je kratak san, 305.; Jure Krišto, "Fra Dominik Mandić i hrvatske izbjeglice 1943. - 1953." [“Fr. Dominik Mandić and Croatian refugees 1943-1953“], in: Dr. fra Dominik Mandić (1889. - 1973.). Zbornik radova sa znanstvenog simpozija održanog u prigodi 40. obljetnice njegove smrti (Mostar - Široki Brijeg, October 23 and 24, 2013), ed. Fra Ante Marić (Mostar - Zagreb: Hercegovačka franjevačka provincija Uznesenja BDM, Franjevačka knjižnica Mostar and Hrvatski institut za povijest, 2014.), p. 698.; Bauer also mentioned the Papal Canteen which gave one free meal a day but was much less tasty and plentiful.

27 HR-HDA-1561, 10.13/3, "Iz zapisnika Danijela Uvanovića" ["From the minutes of Danijel Uvanović"], May 5, 1947, p. 62. According to the same testimony of Uvanović, Budimirović showed his discharge from the Ustasha camp Jasenovac and thus proved that he had been arrested by the Ustashas, whom he nevertheless allowed to use the Zagreb canteen.; Budimirović was arrested at the very beginning of the war, on April 20, 1941, but was soon released. (Jelić-Butić, Hrvatska seljačka stranka, p. 67.)

28 HR-HDA-1561, 1.9/3, “O skrivanju ratnih zločinaca po samostanima i sv. Jeronimu”, August 1948, p. 1a. The mentioned document is the testimony of Eduard Kršul before the Yugoslav investigators, so it is not possible to precisely determine the period during 1945 and 1946 in which the Ustashas had limited access to the Zagreb canteen. Kršul said in his testimony that the main opponents of the Ustasha presence in the canteen and the Brotherhood were priestly circles and Fr. Dominik Mandić, and that Budimirović also defended the Ustashas' entry into the canteen and that the situation changed in mid-1946, but other sources show that it was much earlier.

29 HR-HDA-1561, 1.9/5, "Rad i djelovanje emigracije na području Austrije, Italije i Francuske" ["Work and activities of emigrants in Austria, Italy and France"], August 1948, p. 1a; HR-HDA-1561, 1.9/3, “O skrivanju ratnih zločinaca po samostanima i sv. Jeronimu”, August 1948, p. 2. 
more prominent people from the NDH state system and numerous intellectuals from various scientific branches. ${ }^{30}$

Immediately upon his arrival, Budimirović began to act as a representative of the CPP, which is why Pernar later criticized him. Budimirović thus officially met with Serbian politicians Živko Topalović, Adam Pribičević, Radmilo Grđić and other Serbian leaders in Rome, as well as with the representative of the Slovenes, Miha Krek. ${ }^{31}$ On July 2, 1946, Budimirović prepared a small meal for Topalović, Pribičević, Grđić, Major Jovo Dabović, who was the intendant of the 506th Chetnik Corps, and Major Ciganović, who was an intelligence officer of the priest Momčilo Đujić, in the Zagreb canteen. ${ }^{32}$ On September 6, 1945, he also officially attended a thanksgiving service at the Russian Orthodox Church in Rome for the health of King Peter ${ }^{33}$ which is why he was immediately attacked by Ustasha emigrants. ${ }^{34}$ His cooperation with the Serbs in the first months of his stay in Rome was also registered by a Roman associate of the Yugoslav secret service who wrote: "It is interesting to note for Budimirović that in 1945, after arriving in Italy, and before the arrival of the Pernar-Torbar-Reberski trio, he acted here as a representative of the CPP and not only declared himself to cooperate with the Serbs, but also on the king's birthday, spoke publicly that he was always with the monarchy and that the Karađorđevićs should lead Yugoslavia. However, after the arrival of the trio just mentioned, he was pushed away and quickly returned to the Ustashas and became their faithful Trabant again." ${ }^{35}$

\section{Arrival of Torbar, Pernar and Reberski in Rome, organization, and division}

Torbar, Pernar and Reberski were members of the Maček's inner circle in the pre-war period, ${ }^{36}$ and they arrived in Rome with their families in Octo-

\footnotetext{
30 HR-HDA-1561, 1.9/3, "Hrvatski odbor u Rimu", August 1948, p. 17. A figure of about 200 intellectuals in early 1946 is reported.

31 Ivan Pernar, “Odgovor dr. Pernara na napadaj 'Jeremija' iz Rima” [“Dr. Pernar's response to the attack of 'Jeremiah' from Rome"], Hrvatski glas (December 10, 1946), p. 3.

32 Ibidem.

33 Ibidem.

34 HR-HDA-1561, No. 301884, Dossier Ante Budimirović [Dossier Ante Budimirović], p. 21.

35 HR-HDA-1561, 010.25, "Aktivnost grupe HSS-ovaca u Italiji neposredno poslije II svjetskog rata" ["The activity of a group of CPP members in Italy immediately after World War II"], April 16, 1947, p. 8

36 Petrić, "Prilozi za biografiju hrvatskog političara Josipa Torbara", p. 185.
} 
ber $1945 .{ }^{37}$ It is very probable that Torbar, Pernar, and Reberski set out from Salzburg in early October, and arrived in Rome separately in the space of a few days. Most likely, Torbar was the first to arrive in Rome in the first half of October, and a few days later Pernar, who came to Rome in a uniform with the insignia of the Yugoslav Royal Army ${ }^{38}$, and the last to arrive was Reberski.

37 There are various data on the exact date and order of their arrival in the available sources. According to US military authorities in Salzburg, Pernar, Torbar, Reberski and Vučković fled Salzburg in early October after hearing that Danilo Belanić had been arrested in Salzburg on his way back from Paris to Rome. Belanić was in Paris for consultations with Maček, and he left Paris on October 1 with the task of conveying to the aforementioned the announcement of the appointment of the Central Committee headed by Torbar and that they all went to Rome, but had already gone to Rome when they heard that Belanić arrested. (Robionek, Croatian Political Refugees and the Western Allies: A documented History, p. 301, document from March 1946); According to a report by a Yugoslav secret service associate from Rome on November 8, 1945, Pernar arrived in Rome by car on October 15, 1945, in the uniform of an English officer with the Royal Yugoslav Army insignia. (HR-HDA-1561, 10.13/3, "Dr. Pernar Ivan", November 8, 1945, p. 10.); Unlike the information of the Yugoslav secret service, Draganović wrote in a letter to Lovro Sušić dated October 18, 1945 that Torbar arrived in Rome a few days ago, and Dr. Pernar is expected in the next few days, by which it is evident that Pernar was not yet in Rome on the 15th of October, and it is evident that Pernar and Torbar had not arrived together. (Jareb, "Dr. Krunoslav Draganović o svojem radu u Italiji od rujna 1943. do ožujka 1946.", pp. 592-593.); According to the data of the Yugoslav Secret Service obtained at the end of 1945 , it is written only that Pernar and Torbar moved from Salzburg to Rome and that Pernar came by car in the uniform of an English officer with the insignia "Yugoslav Kingdom". Pernar came with his wife, and Torbar with his two sons. Although the year 1947 was written by hand on the document, it is obvious that it was written at the end of 1945, given that it was entitled "The Last Information from Italy", and the information refers to the time of Pernar and Torbar's arrival in Rome. (HR-HDA-1561, 10.13/3, "Posljednja obavještenja iz Italije" ["Latest announcements from Italy"], 1947., p. 68.); A report by a Drago Ratković, written on February 10, 1947 for the Yugoslav secret service, states that Ratković met Pernar and Torbar in Rome in the summer of 1945. (HR-HDA-1561, 10.13/3, "Italija. Dr. Pernar" [“Italy. Dr. Pernar"], February 10, 1947, p. 59.); An unsigned statement from the interrogation of the arrested emigrant states that Pernar and Vučković were in Rome on November 2, 1945, and Torbar and Reberski arrived only ten days later, and that Pernar used the advantage of his earlier arrival to impose himself in Rome. (HR-HDA-1561, 10.13/3, "Povezanost HSS-a sa ustašama” ["The connection of the CPP with the Ustashas"], August 1948, p. 80; Krizman, Pavelić u bjekstvu, p. 162.); Danijel Uvanović, who was extradited to the Yugoslav authorities in the spring of 1947, said at a hearing in May 1947 that Pernar and Torbar and their families had "somehow at the same time" arrived in Rome, and later Reberski with his wife, son and daughter (HRHDA-1561, 10.13/3, "Iz zapisnika Danijela Uvanovića”, May 5, 1947, p. 62.)

38 Pernar's uniform was commented on by Draganović at a hearing before the Yugoslav investigative bodies in 1967, about which he said at the time: "Pernar was in the uniform of a Yugoslav lieutenant colonel. Because of this, many resented him [...] We knew very well that Dr. Pernar was negotiating in Austria, and that is why he was transferred by King Peter's military mission to Italy, to establish a Yugoslav support society in which he would be vice president and president Dr. Živko Topalović. Knowing this immediately on the first day, I dragged him to my house, prepared a small lunch for him, gave a speech, and told him: 'evil tongues say 
After arriving in Rome, Pernar and Torbar connected with Budimirović and the emigrants in the Zagreb canteen, where they also held a meeting with about 100 prominent emigrants. ${ }^{39}$ At that meeting, Pernar and Torbar gave speeches introducing those present to Maček's activities in Paris and with information on how the British would overthrow the then regime in Yugoslavia and establish democracy, for which they claimed that Maček received a guarantee from the British government through King Peter. In his speech, Pernar emphasized that the king was insecure in his position, so he was inclined to put pressure on the Serbian emigrants to conclude an agreement with Maček and the Slovene Krek. Pernar also said that Yugoslavia should be "broken into" and a new situation established by force, Croats should make propaganda in the camps in Italy and Austria with the aim of forming Croatian military units, which would have their own special characteristics and independence and it should be the real Croatian army. ${ }^{40}$

According to the Yugoslav Secret Service, Pernar and Torbar were temporarily placed in the Monastery of St. Dominic upon their arrival in Rome, where they were assigned an apartment by decision of Pope Pius XII, and Budimirović was placed in the same monastery at the time. According to the same data, Pernar and Torbar were immediately received by the Pope, who promised them all possible moral and financial support while residing in Italy. The Pope allegedly stressed that he had used all his power to overthrow the then Yugoslav regime with the aim of establishing a "New Yugoslavia in which Croats would be guaranteed freedom of religion and political activity". ${ }^{41}$ After that visit, they were received by the Vatican Secretary of State, where they set up a plan for financial assistance and establish a better and more "conspiratorial connection" with the Catholic clergy in Yugoslavia. According to the same information, Pernar and Torbar were greeted in Rome with enthusiasm by Croatian, Serbian and Slovene emigrants, who hoped that they would lead a hitherto heterogeneous Yugoslav political diaspora. ${ }^{42}$

With the arrival of Pernar, Torbar and Reberski in Rome, the organization began, but also the first divisions. At the end of September 1945, Maček

that Dr. Pernar is in the Serbian mission, and that same Pernar carries a Serbian bullet'. This confused him so much that for two whole months he did not bring up the matter at all, for he found himself between two fires." (HR-HDA-1561, 010.24, "Odlazak dr. Mačeka i nekih prvaka Hrvatske seljačke stranke iz Zagreba, uoči ulaska jedinica Jugoslavenske narodne armije”, November 5, 1967., pp. 2-3.; Petrić, "prilozi za biografiju Ivana Pernara (1889.-1967.)”, p. 198.)

39 HR-HDA-1561, 10. 13/3, "Posljednja obaveštenja iz Italije”, 1947, p. 68.

$40 \quad$ Ibidem. p. 68-69.

$41 \quad$ Ibidem. p. 68.

42 Ibidem. 
decided to establish a central CPP committee based in Rome, and proposed Torbar as president. ${ }^{43}$ In the available sources, this committee was called the CPP Central Committee, ${ }^{44}$ the CPP Executive Committee for Italy ${ }^{45}$ and the CPP Main Board for Italy, ${ }^{46}$ and in mid-1946 the Canadian Hrvatski glas mentioned only the "CPP Office in Rome". ${ }^{77}$

After the end of the war and the disintegration of the party, Maček realized that he could not make political progress with such a party situation, especially not in exile, so after consulting with Krnjević, he decided to establish a party committee for two key reasons. The first was the internal homogenization and organization of the party, and the second was a stronger approach to the Allies to show them that not only he and Krnjević were in exile, but the entire party. In addition, the Committee, headed by Maček, was to be a "people's representative body" that would represent the Croatian people and their interests. Torbar, Pernar, Reberski, Božidar Vučković, Budimirović, Zdravko Šutej, Mesuda Kulenović were appointed to the Committee, and a little later Kljaković and Zvonko Mustapić were co-opted. ${ }^{48}$

At first, the committee did not receive any instructions for work, except one, which is to include in the Committee people who had not joined the Ustasha movement and those who signed the "interpellation"49 during the

43 HR-HDA-1561, 010.21, "Emigracija Hrvatske seljačke stranke (HSS)" ["Emigration of the Croatian Peasant Party (CPP)“], May 18, 1946, p. 4.; HR-HDA-1561, 10.13/3, "Reakcija - Izveštaj iz Rima” ["Reaction - Report from Rome“], November 13, 1945, p. 8.; Robionek, Croatian Political Refugees and the Western Allies: A documented History, pp. 300-301.; Schmidt, "Vladko Maček i Hrvatska seljačka stranka: prizori iz izbjeglištva", p. 415.

44 HR-HDA-1561, 10.3/13, "Povezanost HSS-a sa ustašama”, August 1948, p. 80.; HRHDA-1561, 010.25, "Aktivnost grupe HSS-ovaca u Italiji neposredno poslije II svjetskog rata", May 31, 1946, p. 13.; "Pismo Z. Resteku od hrv. sveučilištaraca iz Italije” ["Letter to Z. Restek from cro. university students from Italy"], Hrvatski glas ( September 3, 1946), p. 2.; Robionek, Croatian Political Refugees and the Western Allies: A documented History, pp. 299-301.

45 HR-HDA-1561, 010.21, "Emigracija Hrvatske seljačke stranke (HSS)", May 18, 1946, p. 4.; In September 1946, Pernar signed as a member of the "Executive Committee" in the pit for the dead American pilots. "Croats in Italy Pay Tribute to American Airmen Who Died in Discharge of Their Duty”, Hrvatski glas (October 15, 1946), p. 2.)

46 HR-HDA-1561, 10.1/5, "Aktivnost jugoslavenske emigracije” ["Activity of Yugoslav emigrants"], no date, p. 14.

47 "Važne adrese za pristaše HSS" ["Important addresses for CPP supporters"], Hrvatski glas, July 16, 1946, p. 3.

48 HR-HDA-1561, 010.21, “Emigracija Hrvatske seljačke stranke (HSS)”, May 18, 1946, p. 4.

49 The submission and declaration were signed by 39 deputies at the beginning of the session of the Croatian National Parliament in February 1942, of which 28 were members of the CPP. The submission and declaration demanded an answer as to why Maček was detained and demanded his release from the Jasenovac camp, as well as the abolition of concentration 
parliamentary of the $\mathrm{NDH} .{ }^{50}$ The task of the Committee was to revive the work of the CPP and create party organizations. According to the Yugoslav secret service, it was initially thought that the Committee would have broader powers, and it was particularly intended among the Ustasha emigrants to take over the conduct of a large-scale "conspiratorial-political action" in Yugoslavia that would include terrorist ventures. The Ustasha emigrants were ready to actively support the work, but Maček gave such instructions by which he completely limited the work of the Committee. Maček's later instructions enabled the cooperation of the Ustasha emigrants and CPP members because Maček pointed out that only those Ustashas who had no "sins"51 other than membership in the Ustasha movement could be admitted to the party. Based on these instructions, the Committee tried to create party organizations in refugee camps and in Italian and Austrian towns where Croatian emigrants resided, and commissioners were appointed to carry out these tasks. ${ }^{52}$ By the spring of 1946, the result was weak, ${ }^{53}$ after which CPP committees were established in some Italian refugee camps. ${ }^{54}$ Increased activity in the camps followed in the summer of $1946 .{ }^{55}$

After its establishment, the CPP Committee in Rome held only one session at which members clashed and quarrelled, and the Committee was divided into two groups. On one side were Pernar, Vučković, Kljaković and Mustapić, and on the other side were Reberski and Budimirović, while Torbar and Šutej were neutral. One of the reasons for the division was different political views. Pernar and Vuckovic advocated solutions to a political situation similar to that in the old Yugoslavia with the possibility of compromise with the new Yugoslavia and were in favour of co-operation with the Yugoslav Committe ${ }^{56}$, while Reberski and Budimirović were "irreconcilable opponents" of the

camps and an end to the persecution of Serbs and Jews. (Jelić-Butić, Hrvatska seljačka stran$k a$, pp. 87-89.)

50 HR-HDA-1561, 010.21, “Emigracija Hrvatske seljačke stranke (HSS)”, May 18, 1946, p. 4.

51 Probably the term sin meant crimes.

52 HR-HDA-1561, 010.21, "Emigracija Hrvatske seljačke stranke (HSS)", May 18, 1946, pp. 4-5.

53 HR-HDA-1561, 010.21, "Emigracija Hrvatske seljačke stranke (HSS)", May 18, 1946, pp. 4-5.; Jareb, “Dr. Krunoslav Draganović o svojem radu u Italiji od rujna 1943. do ožujka 1946.", p. 607.

54 HR-HDA-1561, 10.1/5, "Aktivnost jugoslavenske emigracije”, no date, p. 14.

55 HR-HDA-1561, 010.25, "Aktivnost grupe HSS-ovaca u Italiji neposredno poslije II svjetskog rata”, July 25,1946, p. 9.

56 It refers to the Yugoslav National Committee, which was in London, which included refugee leaders of Serbian parties, and the president was former Prime Minister of the refugee government Slobodan Jovanović. Vladko Maček also worked with them on the agreement during 1946. See more: Tepeš, Hrvatska politička emigracija - HSS, pp. 130-138. 
old and new Yugoslavia and advocated co-operation with the Ustasha emigrants. ${ }^{57}$ According to some reports, the quarrel between Pernar and Reberski culminated in a personal and physical confrontation at the time, after which Torbar distanced himself from both. ${ }^{58}$ Allegedly, the background of the division in the Committee was also financial because Pernar kept for himself the money he received from Pavelićs government in Austria to support CPP members Pernar, Torbar, Vučković, Reberski and some other MPs. ${ }^{59}$

Due to the conflict, Pernar gave up going to the Zagreb canteen, which he visited in the first days. ${ }^{60}$ During the first months of 1946, Pernar, as a co-owner, opened the inn "Per tutti" to try to break the influence of the Zagreb canteen and attract people from the group Reberski-Budimirović-Torbar-Šutej to the group Pernar-Vučković-Kljaković-Mustapić. ${ }^{61}$

Unlike Pernar, Reberski spent the entire stay in Rome with his family going to the canteen and having lunch there because everyone lived modestly in a private apartment. ${ }^{62}$ Torbar and his sons visited the canteen most likely until the end of the spring of $1946,{ }^{63}$ and later moved away from the canteen. ${ }^{64}$

Obviously, the conflict between the members within the Committee led to its passivity in collaborative work in early 1946, and the party work was reduced to the activity of individual members, according to Maček's orders

57 HR-HDA-1561, 010.21, “Emigracija Hrvatske seljačke stranke (HSS)”, May 18, 1946, p. 5.; HR-HDA-1561, 10.13/3, "Aktivnost HSS-a u inostranstvu" [“CPP activity abroad"], 1946, p. 48.

58 HR-HDA-1561, 10.13/3, “Italija. Dr. Pernar”, February 10, 1947, p. 59.

59 HR-HDA-1561, 010.21, “Emigracija Hrvatske seljačke stranke (HSS)”, May 18, 1946, p. 25. HR-HDA-1561, 10.13/3, "Osnutak odbora HSS-a" ["Establishment of the CPP Committee"], April 27, 1946, p. 37; It is about 150,000 marks and 250 napoleondors (gold coins)

60 HR-HDA-1561, 010.21, “Emigracija Hrvatske seljačke stranke (HSS)”, May 18, 1946, p. 25. HR-HDA-1561, 10.13/3, “Iz zapisnika Danijela Uvanovića”, May 5, 1947, p. 64.

${ }_{61}$ HR-HDA-1561, 10.13/3, “Osnutak Odbora HSS-a”, April 27, 1946, p. 37.; Pernar's inn is also mentioned by Živan Kuvedžić, a pre-war HSS MP and former Minister in the NDH government, at a hearing before Yugoslav investigators on September 14, 1948. (Vladimir Geiger, Suzana Leček. 'Živan Kuveždić - ministar na saslušanju (Iskaz Živana Kuveždića UDB-i NR Hrvatske u rujnu 1948. o boravku u zarobljeničkim logorima i zatvorima u Italiji i Njemačkoj od svibnja 1945. do kolovoza 1948.)” [““'̌̌ivan Kuveždić - Minister at the hearing (Testimony of Živan Kuveždić to the Secret Service of the People's Republic of Croatia in September 1948 about his stay in prison camps and prisons in Italy and Germany from May 1945 to August 1948)"], Politički zatvorenik 22 (2012) No. 241: 38.); How long the inn has been operating cannot be determined based on available data.

62 HR-HDA-1561, 10.13/3, “Iz zapisnika Danijela Uvanovića”, May 5, 1947, p. 62.; HRHDA-1561, 010.21, “Emigracija Hrvatske seljačke stranke (HSS)”, May 18, 1946, p. 26.

63 HR-HDA-1561, 010.21, “Emigracija Hrvatske seljačke stranke (HSS)”, May 18, 1946, p. 26.

${ }^{64}$ HR-HDA-1561, 10.13/3, “Iz zapisnika Danijela Uvanovića”, May 5, 1947, p. 64. 
and permits from Paris. ${ }^{65}$ At the beginning of February 1946, regardless of the disputes, CPP deputies Torbar, Pernar, Ivan Majcen, Budimirović and Reberski attended a memorial service for Ivo Protulipac ${ }^{66}$, who was killed on 31 January 1946 on a street in Trieste. ${ }^{67}$

The CPP Committee in Rome reactivated its work after Pernar, Vučković and Šuljak were in Paris in late March and early April 1946 with Maček, who approved their work and political views and gave them permission to reorganize. He also gave them instructions for publishing the newspapers Slobodniglas and Obavijesti and tasks to gather all the uncompromised, even the Ustashas in Italy, and to establish a connection with their homeland. ${ }^{68}$ The Committee also maintained political ties with the Vatican and Polish General Anders ${ }^{69}$ in the first half and mid-1946, while the Committee had no contact with Allied military commands, except with a few American officers. On the recommendation of the committee, the Americans employed about twenty Croats in their institutions, and among them were both Torbar's sons. ${ }^{70}$ The committee did not have its own material resources, and occasionally received funds from American Croats, which arrived in Rome through Maček's office in Paris. ${ }^{71}$ The CPP leadership considered the group of CPP members gathered around

65 HR-HDA-1561, 10.1/5, "Aktivnost jugoslavenske emigracije", no date, p. 14.; The inactivity of the CPP committee in early 1946 was obviously so strong that the impression was created that the CPP committee in Rome did not even exist, as evidenced by Draganovićs letter of February 27, 1946, in which he wrote: “There is not even its (CPP's, op. Cit.) formal committee in Rome, although Dr. Pernar, Dr. Torbar, Dr. Reberski and several other so-called compromised MPs do nothing without a Paris warrant, and that means very little." (Jareb, "Dr. Krunoslav Draganović o svojem radu u Italiji od rujna 1943. do ožujka 1946.”, p. 607.)

66 Ivo Protulipac (1899. - 1946.) was a Croatian lawyer and a Catholic activist. He was killed two weeks after this Yugoslav secret service report was written. Namely, the report of the associates of the Yugoslav secret service was written on January 14, 1946, and Dr. Ivo Protulipac was killed by the Yugoslav secret service as the first post-war emigrant victim 17 days later.

67 Mostovac, “Idejno izbjeglištvo: Rim 1945-47”, p. 379.

68 HR-HDA-1561, 010.21, “Emigracija Hrvatske seljačke stranke (HSS)”, May 18, 1946., p. 6.; HR-HDA-1561, 010.2. "Prvaci Hrvatske seljačke stranke u emigraciji", February 3, 1947, pp. 5-6.; There is no information on the realization of the printing of the newspaper Obavijest $i$ in the available sources.

69 The army of Polish General Anders was stationed in Italy near the Fermo camp and numbered about 120,000 soldiers and was hostile to the USSR and communism. Anders' army fought on the side of the British, and at a conference of foreign ministers in London on May 25, 1946, a decision was made to disarm it. (Jandrić, "Saveznički izbjeglički logori počeci otpora hrvatske političke emigracije komunističkom režimu u domovini/logor Fermo/", p. 319.)

70 HR-HDA-1561, 010.21, “Emigracija Hrvatske seljačke stranke (HSS)", May 18, 1946, p. 5.

${ }^{71}$ Ibidem. p. 6. 
the Roman committee to be official representatives in Italy during $1946,{ }^{72}$ and the office in Rome with the prominent names of Torbar and Vučković was among the four most important CPP world addresses. ${ }^{73}$ Maček's connections with Rome during 1946 were also some of the most important because he received the latest news from Yugoslavia through them, and Šuljak, Šutej, Vučković, Babić and Reberski brought mail from Italy to Paris several times. ${ }^{74}$

The Committee published the newspaper Slobodni glas, which was published from April 1946 to October or November $1946,{ }^{75}$ and allegedly stopped publishing at Maček's insistence because Maček believed that every CPP official in Italy started working "on their own" without his approval. ${ }^{76}$ The editor of Slobodni glas was Vučković, with Dinko Šuljak, Vlaho Rajić and Pernar writing in it. ${ }^{77}$ It was distributed throughout Rome and the camps of Fermo, Bagnoli, Eboli and Rimini. ${ }^{78}$ According to some sources, it was also translated into English and delivered to the American intelligence service. ${ }^{79}$ The paper was funded by donations from Croats from the United States and Canada, and it was the subject of controversy with other newspapers that were published among Croatian refugees in Italian camps, such as Hrvatska riě́ and Država. ${ }^{80}$ Slobodni glas was sent to North America, where Hrvatski glas

72 “Treba pomoći našoj sirotinji u Italiji” [“Our poor in Italy should be helped”], Hrvatski glas, July 30, 1946, p. 4.; “Odgovor dr. Pernara na napadaj 'Jeremija' iz Rima”, Hrvatski glas, December 10, 1946, p. 3.

73 "Važne adrese za pristaše HSS", Hrvatski glas, July 16, 1946, p. 3.; The remaining three addresses were from Maček in Paris, Krnjević in London and the "Supreme Council of the CPP for Emigration" in North America.

74 HR-HDA-1561, 010.2, "Prvaci Hrvatske seljačke stranke u emigraciji" ["Leaders of the Croatian Peasant Party in exile"], February 3, 1947, pp. 7-9.

75 “'Slobodni glas' - vjesnik Hrv. Seljačke Stranke” [“'Slobodni glas' - Journal of the Croatian Peasant Party"], Hrvatski glas, June 11, 1946, p. 3.; HR-HDA-1561, 10.13/3, "Stanje kod mačekovaca" ["The situation with Maček's sympathizers"], January 24, 1947, p. 55.

76 HR-HDA-1561, 10.13/3, "Političke grupacije među hrvatskom emigracijom" ["Political groups among Croatian emigrants"], April 16, 1947, p. 57.

77 HR-HDA-1561, 1.8, "Kraći osvrti na veze naših emigranata sa stranom policijom i stranim obavještajnim službama” [Brief reviews of our emigrants' connections with foreign police and foreign intelligence services"], no date, p. 104.

78 HR-HDA-1561, 1.8, "Kraći osvrti na veze naših emigranata sa stranom policijom i stranim obavještajnim službama”, no date, p. 104.; “'Slobodni glas' - vjesnik Hrv. Seljačke Stranke”, Hrvatski glas, June 11, 1946, p. 3.; "Članci i bilješke iz 'Slobodnog Glasa', koji izlazi u Rimu” ["Articles and notes from the 'Slobodni glas', published in Rome"], Hrvatski glas, August 6, 1946, p. 3.

79 Tepeš, Hrvatska politička emigracija - HSS, p. 60.

80 HR-HDA-1561, 1.8., "Kraći osvrti na veze naših emigranata sa stranom policijom i stranim obavještajnim službama”, no date, p. 104.; "Osvrt i poruke 'Slobodnog Glasa”" ["Review and messages from the 'Slobodni glas'“], Hrvatski glas, September 3, 1946, p. 3. 
broadcasted it throughout one page. ${ }^{81}$ Hrvatski glas also ceded its space separately to Pernar and his texts. ${ }^{82}$ Pernar's visit to the chapel of the American airport "Campino" on the scaffold of the five killed American pilots whose plane was shot down by the Yugoslav army on August 19, 1946 on the Yugoslav-Italian border was highlighted. Pernar then laid a wreath and, through an American military chaplain, handed a written condolence letter to the US High Command on behalf of Croatian refugees from Italy and as a member of the Executive Committee of CPP. In his condolences, Pernar emphasized that "The Croatian nation at home and abroad will never forget these noble and glorious victims of the barbarous dictatorial aggression". ${ }^{83}$

At about the same time as Maček allowed the reorganization of the CPP Committee, in April 1946 another group of CPP members participated in the founding of the "Croatian Committee", which in the sources was also called the "Croat Refugee Committee" ${ }^{84}$ The chairman of the committee was Budimirović, the vice-president was Reberski, and Josip Raspudićs ${ }^{85}$ was the secretary. The members were Ivan Čelan, Stipe Matijević, General Matija Čanić, Torbar, Salih Baljić and Franjo Jović, and the advisors were Kljaković, Marko Rusko, Ivica Elijaš, Krsto Spalatin, Msgr Antun Golik and Stjepan Sakač. ${ }^{86}$ Although Torbar was initially listed as a member of the committee, it is very likely that he would soon be leaving it. ${ }^{87}$ Reberski also likely left the committee

81 HR-HDA-1561, 1.8., "Kraći osvrti na veze naših emigranata sa stranom policijom i stranim obavještajnim službama”, no date, p. 104.; “'Slobodni glas' - vjesnik Hrv. Seljačke Stranke”, Hrvatski glas, June 11, 1946, p. 3.; "Članci i bilješke iz «Slobodnog Glasa», koji izlazi u Rimu”, Hrvatski glas, August 6, 1946, p. 3.

82 Ivan Pernar, "U laži su kratke noge" ["There are short legs in the lie"], Hrvatski glas, July 2, 1946, p. 4.; "Pozdrav Pernara Hrv Saboru" ["Greetings from Pernar to the Cro. Congress"], Hrvatski glas, October 15, 1946, p. 1.; Ivan Pernar, "Hrvatska Seljačka Stranka i narodna borba" ["Croatian Peasant Party and the People's Struggle"], Hrvatski glas, November 12, 1946, p. 1.; Ivan Pernar, "Hrvatska Seljačka Stranka i narodna borba", Hrvatski glas, November 19, 1946, p. 3.

83 "Croats in Italy Pay Tribute to American Airmen Who Died in Discharged of Their Duty", Hrvatski glas, October 15, 1946, p. 2.

84 HR-HDA-1561, 10.13/3, “Pismo Petra” ["Peter's letter“], April 30, 1946, p. 45.

85 Josip Raspudić was the secretary of the minister in the NDH government, Andrija Artuković.

86 HR-HDA-1561, 1.9/5, "Rad i djelovanje emigracije na području Austrije, Italije i Francuske”, August 1948, p. 1a.; HR-HDA-1561, 10.13/3, “Iz zapisnika Danijela Uvanovića”, May 5, 1947, p. 63.; Jandrić, "Saveznički izbjeglički logori počeci otpora hrvatske političke emigracije komunističkom režimu u domovini/logor Fermo/", p. 313.

87 According to the report of the Roman collaborators of the Yugoslav secret service from June 26, 1946, Reberski allegedly left the Croatian committee under the pressure of the CPP members from another group but quickly returned. The report says: "When Dr. Reberski joined Budimirovic's Ustasha committee, he was reprimanded by the rest of the leadership and left. [...] However, in the first days of June, he took his place again and constantly goes to 
during the early fall of $1946 .^{88}$ The purpose of this committee was to bring together representatives of all political currents to work together on the care and social assistance of emigrants. ${ }^{89}$ Thus, through political connections in Rome, many Croatian intellectuals were employed in American and British military institutions in various jobs. ${ }^{90}$ The first goal of such work was to ensure the existence of these people, and the second goal was to create personal friendships and connections in American and British circles to show them and explain the purpose of going into exile. According to some testimonies, this won the favour of some senior and junior officers of the Allied armies who then visited the premises of the Zagreb canteen, ${ }^{91}$ so an English officer intervened to release from prison 60 people who were arrested during a raid on the canteen in the spring of $1947 .^{92}$ The establishment of the Croatian Committee greatly disturbed another group of CPP members, so Hrvatski glas, on the establishment of the committee, wrote: "These Ustasha butchers founded a committee led by Pavelićs parliamentarian ${ }^{93}$ Ante Budimirović and some Rasputić (Raspudić, op. Cit.), the most intimate collaborator of the butchers

the sessions of that committee. On this occasion, Dr. Torbar was asked what happened to Reberski. Torbar said that Reberski was told not to go to the Ustasha committee, but that he did not listen". (HR-HDA-1561, 010.25, "Aktivnost grupe HSS-ovaca u Italiji neposredno poslije II svjetskog rata”, July 25, 1946, p. 9.)

88 HR-HDA-1561, 10.13/3, "Politička aktivnost mačekovaca” [“The political activity of Maček's supporters"], October 24, 1946, p. 23.

89 HR-HDA-1561, 10.13/3, “Iz zapisnika Danijela Uvanovića”, May 5, 1947, p. 63.; Lendić, Božji kotači, p. 47.

90 HR-HDA-1561, 1.9/3, "Hrvatski odbor u Rimu”, August 1948, p. 17.; Jandrić, "Saveznički izbjeglički logori počeci otpora hrvatske političke emigracije komunističkom režimu u domovini/logor Fermo/", p. 313.; According to the Yugoslav Secret Service data from April 30, 1946, the group around Reberski and Budimirović regularly received 55,000 lire each month from the Institute of St. Jerome to help the Zagreb canteen, and also received special grants when appointing new cardinals and their stay in Rome on two occasions received 100,000 lire from the American cardinal from Chicago, and a large sum was expected from the Spanish cardinals. (HR-HDA-1561, 10.13/3, "HSS grupa Reberski-Budimirović” [“CPP group Reberski-Budimirović”], April 30, 1946., p. 39)

91 HR-HDA-1561, 1.9/3, "Hrvatski odbor u Rimu”, August 1948, p. 17.; HR-HDA-1561, 1.9/5, "Rad i djelovanje emigracije na području Austrije, Italije i Francuske", August 1948, p. 2.

92 HR-HDA-1561, 1.9/5, "Rad i djelovanje emigracije na području Austrije, Italije i Francuske", August 1948, p. 2.

93 A session of the Croatian National Parliament during the period of the NDH was convened in February 1942 and 93 deputies or deputy deputies of the CPP were invited to it, and 60 of them responded. Among them were later emigrants Budimirović, Čelan, Stjepan Hefer, Nikola Hundrić, Josip Filipović, Ivan Majcen, Stipe Matijević, Spasoje Prce, Janko Tortić and Živan Kuvedžić. Leading figures from Maček's inner circle, including Pernar, Torbar and Reberski, were excluded from the invitation to the session of the Parliament. (Jelić-Butić, Hrvatska seljačka stranka, pp. 64-66.) 
Artuković and Dida Kvaternik. [...] Then Salko Baljić, Pavelić's consul in Ljubljana, and Stipe Matijević, a traitor to the CPP, are on that committee [...] All of this is financed by Pavelićs general Pečnikar". ${ }^{44}$ As a review of this article, Budimirović and Raspudić wrote an article that was published in the Danica newspaper in Chicago ${ }^{95}$ and distributed among Italian refugee camps. ${ }^{96}$ In the text, they attacked Pernar for participating in the Yugoslav Welfare Committee as well as Vučković and Šuljak. ${ }^{97}$ Pernar responded to the attacks with a text in Hrvatski glas in which he concluded that the Croatian Committee was governed by the Ustashas and that General Vilko Pečnikar ${ }^{98}$ was behind it, and called Budimirović "Pavelićs MP" who was voted chairman of the committee by Ustasha votes, while the CPP kept away from that committee. ${ }^{99}$

The conflict was also felt during the commemoration of the anniversary of "the June victims"100, so on June 19, 1946, in Rome, both groups simultaneously organized Holy Mass in different churches. The mass organized by Budimirović and Reberski was attended by 120 people, while the mass organized by Pernar, Vučković and Torbar was attended by 60 people. ${ }^{101}$

The division was also reflected in media-advertising activities, so in June 1946 the group gathered around the Croatian Committee began publishing the newspaper Hrvatska rieč. ${ }^{102}$ The editor-in-chief was Ivo Mrakovčić, and the associates were Ivo Oršanić, Pavao Tijan, Petar Bareza, Janko Skrbin, Rudolf Hraščanec, Raspudić and others from the Croatian Committee. The money for publishing the list was provided by priestly circles and the Ustasha emigrants circles. ${ }^{103}$ The paper was published in only 6 or 7 issues, and accord-

\footnotetext{
94 “Treba pomoć našoj sirotinji u Italiji”, Hrvatski glas, July 30, 1946, p. 4.

95 HR-HDA-1561, 1.9/5, "Političke grupacije i strujanja unutar emigracije" ["Political groupings and currents within emigrants"], June 22, 1947, p. 44.

96 HR-HDA-1561, 1.9/5 "Političke grupacije i strujanja unutar emigracije”, no date, pp. 49-50.

97 The text of the pamphlet was not found by the author of the paper in available sources, but its content can be assumed given Pernar's responses to the attacks from the pamphlet.

98 Vilko Pečnikar (1909. - 1984.) was a general and an Ustasha colonel.

99 “Odgovor dr. Pernara na napadaj 'Jeremija' iz Rima”, Hrvatski glas, December 10, 1946, p. 3.

100 It refers to CPP deputies who died after the assassination in the Belgrade Assembly on June 20, 1928.
}

101 HR HDA 1561, 010.25, “Aktivnost grupe HSS-ovaca u Italiji neposredno poslije II svjetskog rata”, June 12, 1946, p. 11.

102 Kazimir Katalinić, Od poraza do pobjede [From defeat to victory], vol. 1. (Zagreb: Naklada Trpimir 2017.), p. 98.

103 HR-HDA-1561, 10.1/5, “Aktivnost jugoslavenske emigracije”, no date, p. 23. 
ing to some data, the paper served to satisfy Budimirovićs ambitions towards Pernar and Vučković, who published Slobodni glas. ${ }^{104}$

Differences between them were also felt in terms of seeing the solution to the current situation at the time. Pernar advocated an agreement with the Serbs to speed up the action to overthrow Tito, and was characterized as a loyal supporter of King Peter who advocated the view of the old Yugoslavia and wanted a federal Croatia. ${ }^{105}$ Reberski advocated an independent Croatian state with a border on the Drina River, and Budimirović was more in favour of Ustasha emigrants. ${ }^{106}$ Torbar was an absolute opponent of the Serbian royal dynasty and the agreement with Serbian emigrants, as well as the agreement with Ustasha emigrants. He regarded that the CPP must change its program to adapt to modern political developments and that the "Russophile bloc" was stronger than the "Anglophile bloc". Accordingly, he stated that he would support any action that would lead to an agreement with Tito, ${ }^{107}$ and hopes for such an agreement were pinned on by some other CPP members in Italy in the spring of $1946 .^{108}$

Maček maintained direct contacts with the CPP members in Italy from Paris all the time, ${ }^{109}$ so he knew very well about all the above-mentioned arguments and disagreements among the CPP members, but he never gave anyone open support. He supported Vučković and Pernar, considered Torbar his "reliable person", and secretly supported Reberski financially. ${ }^{110}$ Due to mutual

104 HR-HDA-1561, 10.13/3, “Iz zapisnika Danijela Uvanovića”, May 5, 1947, p. 63.

105 CIA Document, "Macek and the National Committee in London", December 13, 1946, https://www.cia.gov/readingroom/docs/CIA-RDP82-00457R000200090009-5.pdf, access achieved January 12, 2021.; HR-HDA-1561, 010.21, "Emigracija Hrvatske seljačke stranke (HSS)", May 18, 1946, p. 6.

106 HR-HDA-1561, 010.21, “Emigracija Hrvatske seljačke stranke (HSS)”, May 18, 1946., p. 7.

107 Mostovac, "Idejno izbjeglištvo: Rim 1945-47”, pp. 373-376.; HR-HDA-1561, 10.13/3, "Politička aktivnost mačekovaca”, October 24, 1946, p. 23.; HR-HDA-1561, “Emigracija Hrvatske seljačke stranke (HSS)", May 18, 1946, p. 6.; Petrić, "Prilozi za biografiju hrvatskog političara Josipa Torbara", p. 193.; In the spring of 1946, Maček also considered an agreement with Tito and worked on it. Also, Torbar's position on the strength of the "Russophile bloc" was not alone, because the vice president of the CPP, August Košutić, suggested that Maček reject reliance on Anglo-Americans and advocated reliance on Russia, following the example of Radić's 1924 policy. Maček rejected Košutićs proposal. Košutić made such proposals to Maček in a letter in mid-1947. (Tepeš, Hrvatska politička emigracija - HSS, pp. 56-57., 69-70.)

108 HR-HDA-1561, 010.25, “Aktivnost grupe HSS-ovaca u Italiji neposredno poslije II svjetskog rata”, February 25, 1946, p. 1.

109 Tepeš, Hrvatska politička emigracija - HSS, p. 60-61.

110 HR-HDA-1561, 10.1/5, "Aktivnost jugoslavenske emigracije”, no date, p. 14.; Confirmation of Maček's financing of Reberski, but also of other CPP members, can be found in the letters of Fr. Karlo Balić, who was active in Rome in those years and who wrote in a letter on January 
disagreements, towards the end of 1946, Maček demanded the suspension of all party-political work in Italy, on the grounds that everyone was working on their own, especially Pernar and Vučković. ${ }^{111}$

At the same time, in the fall of 1946, Maček's popularity among Ustasha emigrants in Italy increased, because of his declaration for an independent Croatia at the congress of Croatian emigrants from the USA and Canada held on September 1, 1946, in Chicago. ${ }^{112}$ Unlike the Ustasha emigrants, which considered it the victory of its conception in exile, Maček's performance was critically observed by Torbar and Pernar. Pernar was disputing Maček's declaration for the Croatian state without leaving the possibility of a federation in Yugoslavia, which Pernar considered to be the interruption of the previous talks on the Croatian-Serbian agreement in exile, which he advocated. Torbar thought the same, but he believed that the communist regime was not worse than the Ustasha regime, emphasizing that the "people's misfortune" was caused precisely by the Ustashas. ${ }^{113}$ Despite the enthusiasm for Maček's speech in Chicago, Ustasha emigrants coldly received information about the talks between Maček and Slobodan Jovanović, the president of the Yugoslav People's Committee in London, which were intense in those days. ${ }^{114}$

Post-war disagreements among CPP refugees were a consequence of their roles during the war and their attitude towards the Ustasha movement and the NDH. The division caught the eye of the Yugoslav secret service, which analysed it in detail during 1946 and $1947,{ }^{115}$ and was visible to the rest of the Croatian emigrants, as Draganović testified. ${ }^{116} \mathrm{CPP}$ members were divided

9, 1947 that Maček sent 250,000 lira from Paris to Rebarski, Torbar 100,000 lira and that the money was also given to CPP members Pernar and Didek. (Vicko Kapitanović, "Fra Karlo Balić i hrvatsko iseljeništvo" ["Fr. Karlo Balić and the Croatian Diaspora"], in: Aktualnost predaje: Zbornik radova medunarodnoga znanstvenog skupa prigodom 100. obljetnice rođenja fra Karla Balića, Split, 6. XI. 1999., ur. Marko Babić (Makarska: Služba Božja, 2003.), p. 276.

111 HR-HDA-1561, 10.13/3, "Političke grupacije među hrvatskom emigracijom", April 16, 1947, p. 57.

112 For more on Maček's participation in the Croatian Emigrants' Congress in Chicago, see: Tepeš, Hrvatska politička emigracija - HSS, pp. 83-85.

113 HR-HDA-1561, 10.13/3, "Kongres u Čikagu i Mačekova izjava” ["The Congress in Chicago and Maček's statement”], September 22, 1946, pp. 21-22.

114 HR-HDA-1561, 10.13/3, "Političke aktivnosti mačekovaca”, October 24, 1946, p. 24.; For more on Maček's talks with Jovanović and the attempt to reach an agreement, see: Tepeš, $\mathrm{Hr}$ vatska politička emigracija - HSS, pp. 130-138.

115 HR-HDA-1561, 010.25, “Aktivnost grupe HSS-ovaca u Italiji neposredno poslije II svjetskog rata", April 16, 1947, pp. 7-8.; HR-HDA-1561. 010.25, "Aktivnost grupe HSS-ovaca u Italiji neposredno poslije II svjetskog rata", May 31, 1946, pp. 13-15.

116 HR-HDA-1561, 010.24, “Odlazak dr. Mačeka i nekih prvaka Hrvatske seljačke stranke iz Zagreba, uoči ulaska jedinica Jugoslavenske narodne armije”, November 5, 1967, pp. 4-5. 
into two basic groups, the "uncompromised" or "pure" and the "compromised" or "parliamentarians", within which there were additional divisions. The group of "pure" included those CPP members who were not connected with the Ustashas or the state system of the NDH during the war. CPP officials Torbar, Pernar and Reberski were included in this group, along with Kljaković, Šutej, Šuljak and Vučković. The group of "compromised" included CPP members who participated in the work of the Croatian National Parliament or held positions in the Ustasha movement and the NDH during the war and remained loyal to Pavelić. This group includes Budimirović, Ivan Majcen, Josip Filipović and journalist Ivo Mrakovčić. The mentioned "compromised" CPP members are also joined by students who have been in Rome since before as "fascist scholarship holders". The "compromised" are said to have boasted of their "mačekovism", condemned the Ustashas and cooperated with the "Chetnik emigrants" upon their arrival in Rome, but were immediately expelled from the CPP leadership after the arrival of Pernar, Torbar and Reberski, and it was made clear that they could not perform under the sign of the CPP, after which the whole group of the "compromised" switched to Ustasha circles. The "pure" challenged the "compromised" right to work in exile as party politicians and "mined" them with Maček at every step, while the "compromised" tried to erase that guilt in the party and to accept them back into the party as if nothing had happened. The "compromised" tried to be on the "party line" by justifying Maček's political moves in exile, but they did not do so publicly so as not to lose their positions in Ustasha emigrant circles, given that they had their material support. ${ }^{117}$ With Maček, the "compromised" still failed to impose themselves, but Krnjević maintained such a bond with them, although he did not recognize them as equals. ${ }^{118}$

The "Pure" were divided into the "official" and "unofficial". The "officials" were those delegated by Maček himself to certain countries or recognized in those countries the right to represent the party, but they did not do anything without Maček's prior approval. In Rome, the "officials" were Torbar, Pernar, Šuljak and some other lower-ranking CPP officials. In the earlier period, immediately after arriving in Rome, Reberski was in that group, but he lost his membership in that group due to joint activities with Ustasha emigrants in the Croatian Committee, so he was considered "unofficial" at the time. CPP members from the "official" group served Maček as official advisers and representatives of the party in the country where they resided, and they were also

117 HR-HDA-1561. 010.25, “Aktivnost grupe HSS-ovaca u Italiji neposredno poslije II svjetskog rata”, May 31, 1946, pp. 14-15.; HR-HDA-1561. 010.25, "Aktivnost grupe HSS-ovaca u Italiji neposredno poslije II svjetskog rata”, April 16, 1947, pp. 7-8.

118 HR-HDA-1561, 010.24, “Odlazak dr. Mačeka i nekih prvaka Hrvatske seljačke stranke iz Zagreba, uoči ulaska jedinica Jugoslavenske narodne armije”, November 5, 1967, pp. 4-5. 
interpreters of party policy. The group of "unofficials" consisted of those CPP members who were recognized as "pure", but regardless of that, they were not officially appointed by Maček as his representatives in the countries of residence. Such was the case in Rome with Colonel Ivan Babić and with Reberski and Miroslav Didek. Each of them was at Maček's house in Paris several times and received some verbal approvals from him to act on behalf of the party, but only as a member of the party, with the proviso that the party was not responsible for their possible work that would compromise the party. For a group of "unofficial" CPP members who stayed in the Fermo and Bagnoli camps, it was noted that they should have belonged to the "compromised" in their past but managed to return to the party and as such appeared in the camps as "mačekovci" and led propaganda for "conversion of other strays". ${ }^{119}$

The "compromised" were also divided into two groups, those who were for cooperation with the Serbs and those who were against that cooperation, but neither of them was of special importance except that it was a link through which certain groups of the Ustasha emigrants acted towards other CPP members. The first group to support co-operation with Serbs consisted of pre-war MPs Filipović, Ivan Majcen and Spasoje Prce. Budimirović was included in the second group, which in its position was closer to the Ustasha emigrants. ${ }^{120}$

CPP members also differed in character and way of life during the exile in Rome. Pernar and Budimirović are characterized as persons who are prone to manipulations of larger amounts of money and as persons of a harder, more explosive, and arrogant nature. In contrast, Torbar lived modestly with his sons and was characterized as a more settled man who spent time on long walks and visiting libraries, museums and lectures around Rome and the Vatican. Reberski also lived modestly with his family, as did Filipović, who made a living from sewing. Vučković is characterized as a young and ambitious man, and in emigrant circles it was suspected for a time that he gave the British plans to arrest people ${ }^{121}$ who were staying around the Institute of

119 HR-HDA-1561. 010.25, "Aktivnost grupe HSS-ovaca u Italiji neposredno poslije II svjetskog rata”, May 31, 1946, pp. 14-15.; HR-HDA-1561. 010.25, “Aktivnost grupe HSS-ovaca u Italiji neposredno poslije II svjetskog rata”, April 16, 1947, pp. 7-8.

120 HR-HDA-1561. 010.25, “Aktivnost grupe HSS-ovaca u Italiji neposredno poslije II svjetskog rata", April 16, 1947, pp. 7-8.

121 Based on available sources, it is difficult to determine whether the rumors about Vučković were true, but it is very likely that some CPP members gave the Allied structures "the most useful information about the Ustashas”. (Jure Krišto, "Zagrebačka Židovka Heda Stern u lovu na Pavelića" ["Zagreb Jew Heda Stern in the hunt for Pavelić"], Časopis za suvremenu povijest 42 (2010), No. 1: 60-61.; Lendić, Božji kotači, pp. 20-22.) 
St. Jerome, and even for that reason Dr. Ivo Omrčanin beat him with an umbrella in front of the British. ${ }^{122}$

Despite the divisions, the Yugoslav secret service considered all CPP members to be speculators who maintained ties with all emigrant groups from Yugoslavia, and registered Pernar's connections with the Italian irredentist, for whom he also wrote newspaper articles attacking Yugoslavia. ${ }^{123}$ Most CPP members in Italy were considered both agents of the British and American intelligence services, with Colonel Ivan Babić being identified as the head of the CPP intelligence service. ${ }^{124}$

\section{CPP in Trieste}

Immediately after the end of the war, Trieste and its surroundings became the scene of disputes between the Allies and Yugoslavia, so the area was therefore an excellent base for the work of the CPP. ${ }^{125}$ Especially because, due to the proximity of Yugoslavia, refugees constantly came to Trieste to bring fresh information, which was important for the CPP's intelligence work and cooperation with the allied intelligence services, as was the case with the CPP representative for Trieste Danilo Belanić, who was also in touch with King Peter's intelligence service. ${ }^{126}$ Belanić arrived in Trieste in June 1945 and immediately organized the CPP in that city and was in direct contact with Maček, but from October 1945 to April 1946 he was imprisoned in Salzburg for incorrect travel

122 HR-HDA-1561, 10.13/3, reports from February 1947 to January 1948, pp. 57-64., 79.; HRHDA-1561, 010.21, “Emigracija Hrvatske seljačke stranke (HSS)”, May 18, 1946, pp. 6-8.; Mostovac, "Idejno izbjeglištvo: Rim 1945-47”, pp. 373-376.; Lendić, Božji kotači, pp. 20-22.

123 HR-HDA-1561, 010.25, "Aktivnost grupe HSS-ovaca u Italiji neposredno poslije II svjetskog rata”, April 16, 1947, p. 7.; HR-HDA-1561, 10.13/3, "Politička aktivnost naše emigracije" ["Political activity of our emigration"], December 24, 1946, p. 29.

124 HR-HDA-1561, 010.25, “Aktivnost grupe HSS-ovaca u Italiji neposredno poslije II svjetskog rata", April 16, 1947, p. 7.; HR-HDA-1561, 010.2, "Prvaci Hrvatske seljačke stranke u emigraciji”, February 3, 1947, p. 41.; Babić's intelligence activities were also registered by the American intelligence service, with the proviso that his activities were directly related to Maček without the knowledge of the CPP group. (Schmidt, "Vladko Maček i Hrvatska seljačka stranka: prizori iz izbjeglištva”, pp. 417-419.)

125 Robionek, Croatian Political Refugees and the Western Allies: A documented History, p. 118.; HR-HDA-1561, 010.2, "Prvaci Hrvatske seljačke stranke u emigraciji”, February 3, 1947, p. 9.

126 Robionek, Croatian Political Refugees and the Western Allies: A documented History, p. 302.; Schmidt, "Vladko Maček i Hrvatska seljačka stranka: prizori iz izbjeglištva", p. 416. 
documents he used when traveling from Maček's place in Paris. ${ }^{127}$ Along with Belanić, Dr. Gašpar Malvić, Slavko Kovačić and Pajo Mladineo, people from the former CPP leadership in Croatia, arrived in Trieste immediately after the end of the war. ${ }^{128}$ Trieste, as the closest point to Yugoslavia, came to the fore in December 1945 when Maček sent Eugene Laxa to organize a network and establish a connection with the Crusaders, but Laxa's mission ended in failure. ${ }^{129}$

At the time when Belanić was imprisoned, the activities of the CPP in Trieste were led by Malvić, who also made a list of those interested in moving to New Zealand and Australia, but in mid-January 1946, according to the Yugoslav secret service, the most active member of the CPP was Dr. Ivo Protulipac, who was described as "pretending to be a member of the CPP but is really a clerical Ustasha" ${ }^{130}$ Priest Božo Milanović ${ }^{131}$ and his friends Petar Pribetić and Ivan Šuflaj were registered as active CPP members in Trieste in mid-January 1946, noting that Milanović was more moderate and took the position that Trieste should be annexed to Yugoslavia, praised the attitude and work of the partisans in the Julian Krajina, and criticized the Ustasha emigrants and the work of Draganović and the Brotherhood of St. Jerome, arguing that they were pursuing an "anti-national policy". Pavlec and Mladen Smoljan, the son of former CPP minister Bariša Smoljan, are also listed as active CPP members. Later, during the summer of 1946, Slavko Kovačić and Josip Kralj were also listed as active CPP members in Trieste. ${ }^{132}$

After his release from prison in April 1946, Belanić became active again in Trieste and continued to cooperate with some parts of the Chetnik em-

\footnotetext{
127 Robionek, Croatian Political Refugees and the Western Allies: A documented History, pp. 299., 302.

128 HR-HDA-1561, 10.13/3, “Aktivnost HSS-a u inostranstvu”, 1946, p. 49.

129 Schmidt, "Vladko Maček i Hrvatska seljačka stranka: prizori iz izbjeglištva", p. 417.

130 HR-HDA-1561, 010.25, “Aktivnost grupe HSS-ovaca u Italiji neposredno poslije II svjetskog rata", January 14, 1947, p. 2.; Protulipac was also mentioned as a member of the CPP by the newspaper Slobodni glas, whose texts were transmitted by the Canadian Hrvatski glas. ("Kratke vijesti iz 'Slobodnog Glasa”" [“Short news from the 'Slobodni glas'”], Hrvatski glas, June 11, 1946, p. 3.)

131 Božo Milanović (1890. - 1980.) was a Croatian priest, theologian, and politician. He worked in Trieste for 25 years until he moved to Pazin on November 26, 1946. See: Božo Milanović, Istra u dvadesetom stoljeću [Istria in the twentieth century], vol. 2 (Pazin: "Josip Turčinović" d.o.o., 1996.), p. 190.

132 HR-HDA-1561, 010.25, "Aktivnost grupe HSS-ovaca u Italiji neposredno poslije II svjetskog rata", January 14, 1946, p. 2; HR-HDA-1561, 010.25, "Aktivnost grupe HSS-ovaca u Italiji neposredno poslije II svjetskog rata", August 1946, p. 3.
} 
igrants. ${ }^{133}$ Belanić also received the task of launching the Hrvatski dnevnik newspaper from Maček, ${ }^{134}$ and in July 1946 he offered the Allies the "services" of the CPP in Istria and the Venice-Gulia region, thus proposing the settlement of 2,000 Croats in areas that provoked the Allied dispute and Yugoslavia in order to counterbalance the communist votes. He even proposed the formation of terrorist groups that would drive the communists out of those areas, but the American intelligence service did not adopt those plans. ${ }^{135}$ During the summer of 1946, there were some short-lived thoughts by the CPP leadership that the party would run in the next elections for the Trieste parliament, so the party representatives were given the task of developing as active an activity as possible among the locals. ${ }^{136}$ Although Belanić was still active, in the further period during 1946 and until the summer of 1947 the leading role in the CPP in Trieste was played by Mavlić, who was the choice of Pernar and Vučković and who maintained a permanent connection with Rome. ${ }^{137}$

\section{CPP in Italian refugee camps and helping refugees}

Many Croatian refugees passed through Italy in the first post-war years and estimates of their numbers vary. Draganovićs estimate in February 1946 was that there were between 10,000 and 15,000 Croatian emigrants in Italy, ${ }^{138}$ while Fr. Karlo Balić estimated that there were 25,000 Croatian refugees in Rome at the time. ${ }^{139}$ British military records from early 1946. show that there were 22,787 refugees from Yugoslavia in Italy. ${ }^{140}$ According to some Ameri-

\footnotetext{
133 HR-HDA-1561, 010.25, “Aktivnost grupe HSS-ovaca u Italiji neposredno poslije II svjetskog rata”, August 1946, p. 3.

134 Tepeš, Hrvatska politička emigracija - HSS, p. 61.; There is no data in the available sources to indicated that the printing of Hrvatski dnevnik was realized.

135 Robionek, Croatian Political Refugees and the Western Allies: A documented History, p. 118.

136 HR-HDA-1561, 010.25, “Aktivnost grupe HSS-ovaca u Italiji neposredno poslije II svjetskog rata”, August 1946, p. 3.

137 HR-HDA-1561, 010.25, "Aktivnost grupe HSS-ovaca u Italiji neposredno poslije II svjetskog rata”, April 16, 1947, p. 7.; HR-HDA-1561, 10.13/3, "Povezanost HSS-a s ustašama”, August 1948, p. 81 .

138 Jareb, “Dr. Krunoslav Draganović o svojem radu u Italiji od rujna 1943. do ožujka 1946.", p. 605.

139 Kapitanović, "Fra Karlo Balić i hrvatsko iseljeništvo”, p. 279.

140 Marica Karakaš Obradov, “'Depoi špijuna i terorista'. Saveznički logori za 'raseljene osobe' u Italiji, Austriji i Njemačkoj” [“'Depots of spies and terrorists'. Allied camps for 'displaced persons' in Italy, Austria and Germany"], in: 1945. - Kraj ili novi početak: Tematski zbornik radova, ed. Zoran Janjetović (Beograd: Institut za noviju istoriju Srbije, 2016.), p. 313.
} 
can estimates, there were between 10,000 and 12,000 Croatian emigrants in Trieste, Rome, and southern Austria in the post-war period, most of whom were Ustashas, and there were only 2,000 to 3,000 CPP members. ${ }^{141}$ At the beginning of 1947, Fr. Balić estimated that there were about 35,000 refugees in Rome. ${ }^{142}$

During 1945 and in the first half of 1946, the organization of CPP members in camps with Croatian refugees was weak, and some who tried to do so, as was the case in the spring of 1946 in the Fermo camp, were physically attacked by the Ustashas emigrants, so no one then dared to do so, and all the influence in the camps had the Ustasha emigrants. ${ }^{143}$ The CPP's influence, especially in Fermo and Bagnoli, intensified during the summer and fall of 1946, not because of the activities of the CPP leadership in Italy, but as a consequence of the return to the CPP ranks of that part of the Ustasha emigrants who belonged to the CPP before the war, so they joined the Ustashas during the war, and after the war they realized that from the continuation of the Ustasha policy there would be nothing, but the future was again in the CPP policy. ${ }^{144}$ The accession of refugees to the CPP was also of a practical nature as a result of mutual interest. Refugees needed the CPP to regulate their status more easily, and the CPP needed refugees to increase membership and thus strengthen its reputation in front of the Allies. The core of these relations was best explained by Torbar, who told the Yugoslav agent: "When they (Allies, op. Cit.) address us as the legal representatives of the Croatian people, and regarding the problems of accommodation of Croatian refugees, then we cannot say that we do not actually have our own refugees, that these people do not concern us at all and to present ourselves in this way politically and morally weak. We need these people, and we want to get all those who are morally usable out of the Ustasha mud and at least somehow save them. And the fact that the Allies are helping us, so they are addressing us, exclusively us, is in our favour. Jobs are obtained through us, referrals for the camp are obtained through us, evictions will be carried out through us, certificates of non-collaborationism will be given, etc. For the same reason that we did not have ten people with us in the first days of exile, for that reason today we have all the people in the Bagnoli camp, most of the people from Rome and organized groups in many other places." 145

141 Schmidt, "Vladko Maček i Hrvatska seljačka stranka: prizori iz izbjeglištva”, p. 420.

142 Kapitanović, "Fra Karlo Balić i hrvatsko iseljeništvo”, p. 279.

143 HR-HDA-1561, 10.13/3, “Osnutak odbora HSS-a”, April 27, 1946, p. 36.

144 HR-HDA-1561, 10.13/3, "Politička aktivnost mačekovaca", October 24, 1946, p. 23.

145 HR-HDA-1561, 10.13/3, “Politička aktivnost naše emigracije”, December 24, 1946, pp. 30-31. 
Among the first CPP camp committees established was the one in the Jesi camp, which was established in April 1946. The Jesi camp was located not far west of Ancona and was divided into three parts, each part having one CPP commissioner, and all three commissioners made up the CPP administration in that camp. ${ }^{146}$ As early as June 1946, Vučković called the situation for the CPP in the Jesi camp excellent. ${ }^{147}$

The establishment of the committee was somewhat slower in the largest camps, Fermo and Bagnoli.

Camp Fermo, located south of Ancona, was the camp with the largest number of Croats. About 3,000 Croatian refugees passed through Fermo, and it operated from May 1945 to the fall of $1947 .{ }^{148}$ An example of the hostile attitude of Ustasha emigrants towards the CPP in Fermo, in addition to the aforementioned physical attack on the CPP commissioner, is Danijel Crljen's public lecture on May 25, 1946, in which he sharply attacked Maček as a traitor to the Croatian state because he had not yet declared himself for the Croatian state, accusing him of being willing to make an agreement either with Tito or with King Peter. The day after Crljen, Vinko Nikolić, Stijepo Buć and Dragutin Došen also condemned Maček's policy in a discussion in the camp. ${ }^{149}$ Somewhat later, in June or July 1946, the CPP members participated in the elections for the Fermo camp administration as part of the opposition list led by Dr. Drago Jelić, the brother of the emigrant Branko Jelić. ${ }^{150}$ The opposition received about 600 votes, and the list led by then-camp president Dušan Žanko won by 900 votes. In the campaign before the elections, leaflets and stickers were distributed around the camp depicting oppositionists and CPP members as Tito's sympathizers and Chetniks and wearing hats with communist and Chetnik symbols. ${ }^{151}$

Somewhat later, during the summer of 1946, a temporary CPP committee was established in Fermo, headed by Božo Steinfl, a former colonel of the NDH labor service, and the secretary of the committee was Ivo Jadrešić. The

\footnotetext{
146 "Članci i bilješke iz - «Slobodnog Glasa〉, koji izlazi u Rimu” ["Articles and notes from 'Slobodni Glas', published in Rome”], Hrvatski glas, August 6, 1946, p. 3.

147 HR-HDA-1561, 010.25, “Aktivnost grupe HSS-ovaca u Italiji neposredno poslije II svjetskog rata", June 12, 1946, p. 11.

148 Jandrić, "Saveznički izbjeglički logori počeci otpora hrvatske političke emigracije komunističkom režimu u domovini/logor Fermo/", p. 315.

149 HR-HDA-1561, 1.9/5, "Političke grupacije i strujanja unutar emigracije", no date, p. 49.; HR-HDA-1561, 010.25, "Aktivnost grupe HSS-ovaca u Italiji neposredno poslije II svjetskog rata”, June 12, 1946, p. 11.

150 HR-HDA-1561, 10.1/5, “Aktivnost jugoslavenske emigracije”, April 2, 1948, p. 19.

151 HR-HDA-1561, 1.9/5 "Političke grupacije i strujanja unutar emigracije”, no date, p. 48.
} 
members of the committee were also Vladimir Sinković, Dr. Tomica Bulat, Ivo Šarinić - journalist, Nikola Špalj - district head and engineer Aleksandar Despot. Along with the leadership of the CPP, new members were admitted, including former members of the Ustasha movement who were not compromised by the crimes, so there were about 450 members of the CPP in Fermo at the time. ${ }^{152}$

From Fermo, a larger group of CPP members was moved to the Bagnoli camp near Naples in August 1946. Since then, Bagnoli has been under the CPP control because most of the refugees were organized in the CPP, and their leader Steinfl was elected to the camp administration. From the camp, Steinfl maintained ties with Maček during his stay in Paris, with Krnjević in London and with Canadian CPP organizations. ${ }^{153}$

And in August 1947. many CPP members from Fermo were moved to Bagnoli. Given that there was great tension and intolerance in Fermo between CPP members and Ustasha emigrants, the CPP leadership from Fermo decided to seek approval through the Allies in Rome to move CPP members, as the only representatives of democracy, to another camp, because for them further stay in the Fermo with Ustasha emigrants was impossible. A list of members was compiled and, together with Pernar's request for relocation, submitted to the Allied Refugee Command in Rome, and on August 13, 1947, a group of about 500 people was transferred to Bagnoli, and two days later, on August 15, Pernar arrived at the camp from Rome to intervene because of an intra-party conflict caused by the dissatisfaction of some members with Steinfl. But apparently the coup against Steinfl failed. ${ }^{154}$

The CPP also had a certain influence in the Eboli camp through the Croatian Academic Club, which operated in that camp and which had about 40 young men and women as members. ${ }^{155}$ The camp was mostly occupied by Chetnik refugee units, and the CPP was for a time in Eboli connected with the Croatian part of the royal army, namely the Croatian Army of the Yugoslav Army in the Homeland (Hrvatska Armija Jugoslavenske Vojske u Domovini; HAJVUD) and its commander General Matija Parac. This unit was under the

\footnotetext{
152 HR-HDA-1561, 010.25, "Aktivnost grupe HSS-ovaca u Italiji neposredno poslije II svjetskog rata”, September 1, 1947, p. 4.

153 HR-HDA-1561, 10.1/5, “Aktivnost jugoslavenske emigracije”, April 2, 1948, p. 20.; HR-HDA-1561, 10.13/3, "Politička aktivnost mačekovaca", October 24, 1946, 23.

154 HR-HDA-1561, 010.25, “Aktivnost grupe HSS-ovaca u Italiji neposredno poslije II svjetskog rata", September 1, 1947, p. 4.

155 "Pismo Z. Resteku od hrv. sveučilištaraca iz Italije”, Hrvatski glas, September 3, 1946, p. 2.; "Dvije čestitke i zahvale iz Italije" ["Two greeting cards and letters of thanks from Italy"], Hrvatski glas, April 8, 1947, p. 1.
} 
command of Draža Mihailović during the war, and after the war Parac and part of his men found themselves in Italy. At first, during 1945, the unit numbered between 1,100 and 1,500 people, then at the beginning of 1946 there were less than 200 people, and in October 1946 about 106 people, and at the beginning of 1947 there were 250 members of HAJVUD. ${ }^{156}$

In the fall of 1945, confusion arose among the emigrants when General Parac's leaflet with written correspondence between him and Maček appeared in Italian camps, which upset a large part of the anti-Yugoslav emigrants. ${ }^{157} \mathrm{At}$ the end of February 1946, Draganović called these letters forgeries. ${ }^{158}$ The CPP refused to cooperate with Parac during May 1946, considering him a "preparation of Greater Serbia", but the situation changed the following month. Namely, Parac did not give up seeking the support of the CPP, so on June 17, 1946, he went to Rome, and before his departure from Eboli he spread the rumour that he had Maček's authority to be the only Croatian recognized military commander. Accompanied by four officers dressed in Yugoslav Royal Army uniforms, Parac appeared uninvited at a memorial service for the June victims in Rome on June 19 but was ignored by CPP deputies. However, a meeting was held the next day between him and Pernar at which an agreement was reached. ${ }^{159}$ According to the agreement, Parac recognized the supreme leadership of the CPP and agreed to obey the decisions of the party committee in Rome. It was agreed that HAJVUD would remain in Eboli until further notice, until a special CPP camp was established. It was concluded that as soon as possible, all Serbian officers commanding within HAJVUD must be replaced by Croatian officers, who will be sent by the party from Rome. The party has appointed Mušić as its permanent envoy to HAJVUD, who was to maintain ties between Parac and the party committee in Rome, and the party has pledged to send envoys to Eboli as soon as possible to officially inform the people of the new situation. Parac returned to the camp on June 24, 1946,

156 Karakaš Obradov, “'Depoi špijuna i terorista'. Saveznički logori za 'raseljene osobe’ u Italiji, Austriji i Njemačkoj” pp. 327-328.; Jareb, “Dr. Krunoslav Draganović o svojem radu u Italiji, od rujna 1943. do ožujka 1946.”, pp. 608-609.; Robionek, Croatian Political Refugees and the Western Allies: A documented History, p. 116.; Matija Parac was a brigadier general of the Yugoslav army married to a Serbian woman, and from April 1941 to the end of 1944 he lived in Belgrade. (Jareb, "Dr. Krunoslav Draganović o svojem radu u Italiji, od rujna 1943. do ožujka 1946.", p. 609.)

157 Nikolić, Tragedija se dogodila u svibnju, vol. 1, pp. 427-430

158 Jareb, “Dr. Krunoslav Draganović o svojem radu u Italiji od rujna 1943. do ožujka 1946.", p. 609.; Robionek, Croatian Political Refugees and the Western Allies: A documented History, p. 116.

159 HR-HDA-1561, 010.25, “Aktivnost grupe HSS-ovaca u Italiji neposredno poslije II svjetskog rata”, July 25, 1946, pp. 10., 12., HR-HDA-1561, 010.25, "Aktivnost grupe HSS-ovaca u Italiji neposredno poslije II svjetskog rata”, May 31, 1946, p. 14. 
and Miroslav Didek and Mušić arrived at the beginning of July as party envoys to "inspect" the people. ${ }^{160}$ Parac also sent his delegation from Eboli to celebrate Maček's birthday in Rome in July 1946, and Torbar constantly criticized the agreements between Pernar and Parac. Parac also sent his delegation from Eboli to celebrate Maček's birthday in Rome in July 1946, but despite everything, Torbar constantly criticized the agreements between Pernar and Parac. ${ }^{161}$ In the further period, the available sources no longer contain any information about any closer cooperation between the CPP and General Parac, except for the publicly published Easter greeting sent by Parac to the CPP's Hrvatski glas, ${ }^{162}$ shortly before the camp closed in April 1947. ${ }^{163}$

The CPP camp committees were supported by the official Roman party committee, while at the same time Budimirović's Croatian committee developed cooperation with groups of Ustasha emigrants and the so-called clerical emigration who intended to found the Croatian People's Party (Hrvatska Pučka Stranka) in the camps. ${ }^{164}$

The CPP office in Rome was a link between Croatian refugees from Italy and CPP organizations in Canada and the United States. Based on the lists of refugees obtained from Italy, organizations from the USA and Canada helped through their members to find relatives in those countries, who would give a guarantee, because it was a condition for immigration, which brought success. This was especially intensified after the CPP Committee for Immigration to Canada was established in Canada in early June 1946, and a similar committee was established in early September in the United States. ${ }^{165}$ The Yugoslav Secret Service noted that these committees were working not only to transfer CPP members, but also Ustashas. ${ }^{166}$ Apart from the offices in Rome, the Canadian and American CPP members maintained direct contact with

160 HR-HDA-1561, 010.25, “Aktivnost grupe HSS-ovaca u Italiji neposredno poslije II svjetskog rata”, July 25, 1946, p. 10.

161 Ibidem. p. 10, 12.

162 “Dvije čestitke i zahvale iz Italije”, Hrvatski glas (April 8, 1947), p. 1.

163 Karakaš Obradov, “Depoi špijuna i terorista'. Saveznički logori za 'raseljene osobe' u Italiji, Austriji i Njemačkoj”, p. 328.

164 HR-HDA-1561, 1.9/5 "Političke grupacije i strujanja unutar emigracije", no date, pp. 48-49.

165 "Obavijest kanadskog odbora za useljavanje u Kanadu" ["Notice from the Canadian Committee on Immigration to Canada"], Hrvatski glas (August 6, 1946), p. 4.; "Traže rodbinu u Kanadi i Sjed. Državama" ["They are looking for relatives in Canada and the United States"], Hrvatski glas, August 6, 1946, p. 4.; "Pismo uredniku od Hrv. akademskog kluba u Italiji” [“'Letter to the editor from the Croatian Academic Club in Italy"], Hrvatski glas, December 10, 1946, p. 2.; HR-HDA-1561, 010.2, "Prvaci Hrvatske seljačke stranke u emigraciji”, February 3, 1947, p. 13.; Tepeš, Hrvatska politička emigracija - HSS, pp. 82-83.

166 Tepeš, Hrvatska politička emigracija - HSS, p. 83. 
the camps, ${ }^{167}$ and also helped the refugees financially from the "Dr. Vladko Maček Fund for the Freedom of Croatia" ${ }^{168}$ Assistance in relocating Croatian refugees from Italy to Canada was also provided by the Canadian ambassador in Paris, with whom Maček maintained good relations. ${ }^{169}$

In late 1946 and early 1947, the CPP established closer cooperation with the Brotherhood of St. Jerome, so a joint Committee for Emigration was established, consisting of Draganović, Mađerec, Pernar, Torbar, Vlaho Rajić and Pavao Jesih. ${ }^{170}$ During December 1946, Pernar, Draganović and Mađerec sent a memorandum to President Juan Perón to relocate Croatian refugees to Argentina, ${ }^{171}$ then on December 24, Pernar and Mađerec jointly sent a request to the Prime Minister of South Africa to accept Croatian refugees from Italy, Austria and Germany. ${ }^{172}$ The American intelligence service registered data according to which the Committee, with the help of the "Assistenza Pontifica" and the "International Refugee Committee", evacuated "Ustasha war criminals" on the ship "Andrea Griff”, which sailed for South America on December 29, 1946. ${ }^{173}$ Valuable assistance to the committee was also provided by the Argentine Embassy in Rome, which, on the basis of instructions received from

167 HR-HDA-1561, 1.9/1, "Veze sa reakcionarnim iseljeničkim organizacijama u Americi” [““'Relations with reactionary emigrant organizations in America”], no date, p. 10.

168 "Za slobodu Hrvatske - fond Mačeka" ["For the Freedom of Croatia - Maček Fund"], Hrvatski glas (November 19, 1946), p. 4.

169 HR-HDA-1561, 010.2, "Prvaci Hrvatske seljačke stranke u emigraciji”, February 3, 1947, p. 10.

170 Kapitanović, "Fra Karlo Balić i hrvatsko iseljeništvo”, p. 279.; Lukinović, "Bratovština svetog Jeronima za pomoć hrvatskim izbjeglicama", p. 828.; CIA DOCUMENT, "Evacuation of Croats from Italy", May 14, 1947, https://www.cia.gov/readingroom/docs/CIA-RDP8200457R000600010001-7.pdf - access achieved January 7, 2021.; In the document of the American intelligence service, Mađerec and Draganović were called Ustashas, and it was written for the committee that it was a "joint Ustashi-Croat welfare committee". The terms used in the US intelligence document may be the result of a vocabulary used by a service associate who did not necessarily have to be American, given that there were people from Yugoslavia in the service, and there were those who provided information to the US and Yugoslav service. See example in: Tepeš, Hrvatska politička emigracija - HSS, p. 68.

171 Kapitanović, “Fra Karlo Balić i hrvatsko iseljeništvo”, p. 279.

172 "Molba premijeru južne Afrike sa strane naših ljudi u Italiji” ["A request to the Prime Minister of South Africa from our people in Italy"], Hrvatski glas, February 4, 1947, p. 1.; According to available data, it is not known how long Pernar was active in that committee. Pernar is mentioned from the minutes of the Brotherhood at the end of January, and there is another information from the minutes from the session held on March 13, 1947, in which it is written: "Pernar refuses to participate in the sessions of the emigrant commission, offended that he was not admitted to the sessions of the BSJ committee (Brotherhood of St. Jerome, op. Cit.)”. (Lukinović, “Bratovština svetog Jeronima za pomoć hrvatskim izbjeglicama”, p. 828.)

173 CIA DOCUMENT, “Evacuation of Croats from Italy”, May 14, 1947, https://www.cia.gov/ readingroom/docs/CIA-RDP82-00457R000600010001-7.pdf - access achieved January 7, 2021. 
Argentina, approved visas for the departure of 30,000 Croats to Argentina in the period from March 1 to June 1, 1947. ${ }^{174}$ Maček was also acquainted with the whole activity of the relocation of Croats to Argentina, because he talked about it with Reberski, who visited him in Paris at the beginning of $1947 .{ }^{175}$

One part of the CPP members did not cooperate only with Croats in terms of refugee care, so Pernar, Vučković, Šuljak, Didek and Mušić were members of the Yugoslav Welfare Society, whose committee included Slovenes, Croats, and Serbs. The Society was founded before the arrival of Croatian emigrants in Rome, and before the inclusion of the CPP members, the rules of the Society were changed so that the Croatian representation was completely independent and autonomous in its work of caring for Croatian refugees. The president of the Society was the Slovene Miha Krek, the general secretary was the Serb Radmilo Grđić, and Pernar was the vice president. The Society maintained liaison with the Yugoslav Committee in London and Konstantin Fotić in the United States. ${ }^{176}$ The Society had material support and food aid from the American Red Cross and the United Nations Relief and Rehabilitation Administration (UNRRA), and the Society's membership card, at a time when there were many Allied armies and their canteens and canteens in Rome, allowed individuals to in these canteens they dine for free or at a very small price. For a time, the Society also had its own civilian canteen, and it also had its own office in which various personal documents were issued and certified, the validity of which was recognized by both the Allied and Italian authorities. According to some data, few Croats, except for some students, addressed the committee. ${ }^{177}$

Pernar claimed that he and his party associates joined the Society with Maček's approval for the material protection of Croatian refugees in Italy, and that only through that Society could the material benefits of Croatian refugees be represented and employed by the allied authorities. He also claimed that the Allied authorities in Italy unofficially recognized the Society as the only representation of Serbs, Croats and Slovenes in the employment and resettlement of refugees from Yugoslavia. He cited the example of Reberski's

\footnotetext{
174 Ibidem.

175 Ibidem. In that document, Reberski is addressed as a former minister who is the link between Maček and Pavelić.

176 HR-HDA-1561, 1.9/1, "Veze izmedju pojedinih emigrantskih grupa" ["Links between certain emigrant groups”], June 23, 1947, p. 6.; HR-HDA-1561, 1.9/3, “Izjava Danijela Uvanovića”, May 13, 1947, p. 20; HR-HDA-1561, 10.13/3, "Političke grupacije medju Hrvatskom emigracijom”, April 16, 1947, p. 57.; "Odgovor dr. Pernara na napadaj 'Jeremija' iz Rima”, Hrvatski glas, December 10, 1946, p. 3.

177 HR-HDA-1561, 1.9/3, “Izjava Danijela Uvanovića” [“Statement by Danijel Uvanović”, May 13, 1947, p. 20
} 
son, who was the first Croat employed by the Allied authorities through the Society, by which he wanted to confirm how inevitable it was for Croatian refugees to use that Society for the protection of material interests. Pernar concluded that there was no other way to alleviate the poverty of many Croatian refugees in Italy. ${ }^{178}$ Pernar made allegations about his work in Yugoslav society in response to criticism from many Croatian emigrants. He was criticized for cooperating with Serbs in the Society and was accused of taking a commission from those he managed to hire. ${ }^{179}$ One of the critics was Reberski, who claimed that Pernar did not have Maček's permission to work in the Society. ${ }^{180}$ Some emigrants resented him for cooperating with the royal and pro-Chetnik oriented Serbs in that committee, so Budimirović called him a Chetnik. ${ }^{181}$ Despite the criticism, it is obvious that Pernar had great power in that Society, and through the Society he also had a great influence among the British because only on his recommendation was it possible to relocate refugees to South Africa. Pernar himself claimed that the purpose of his activities in that Society was to enable the relocation of Croatian refugees to overseas countries, especially to British dominions. ${ }^{182}$

Although in the middle of 1946 the main activity of the CPP leadership in Italy was focused on emigration, even then all hope was not lost that with some compromise he could return to his homeland in the fall of that year. ${ }^{183}$ Although there was hope, the CPP members in Italy were ready for a longterm emigration from the beginning of $1946,{ }^{184}$ and at the end of the year such a message was sent to them by Maček with a recommendation to start looking for countries in which to live. ${ }^{185}$ At the same time, in late 1946 and early 1947, dissatisfaction was felt with the party's work and Maček's moves, and Torbar was especially pessimistic, believing that the CPP was disoriented and that

\footnotetext{
178 “Odgovor dr. Pernara na napadaj 'Jeremija’ iz Rima”, Hrvatski glas, December 10, 1946, p. 3.

179 HR-HDA-1561, 10.13/3, “Italija. Dr. Pernar”, February 10, 1947, p. 59.

180 HR-HDA-1561, 010.25, “Aktivnost grupe HSS-ovaca u Italiji neposredno poslije II svjetskog rata”, June 26, 1946, p. 10.

181 HR-HDA-1561, 10.13/3, “Iz zapisnika Danijela Uvanovića”, May 5, 1947, p. 64.; HRHDA-1561, 10.13/3, "Iskaz Josipa Jezovšeka” [“Testimony of Josip Jezovšek”], August 1948, p. 75 182 HR-HDA-1561, 10.13/3, "Iskaz Josipa Jezovšeka”, August 1948, p. 75

183 HR-HDA-1561, 010.25, “Aktivnost grupe HSS-ovaca u Italiji neposredno poslije II svjetskog rata”, June 26, 1946, p. 9.

184 HR-HDA-1561, 010.25, “Aktivnost grupe HSS-ovaca u Italiji neposredno poslije II svjetskog rata”, January 14, 1946, p. 2.

185 HR-HDA-1561, 10.13/3, “Političke grupacije među emigracijom” ["Political groups among emigrants”], April 16, 1947, p. 57.
} 
the CPP leadership should not leave Croatia. ${ }^{186}$ Prominent CPP members were more inclined to leave Italy for Canada, due to the strong CPP organizations in that country, but this was not possible at the time. Some CPP members were not inclined to go to Argentina because they thought that there was a strong Ustasha diaspora that would be a strong opposition, and the proponents of this thesis were Pernar, Vučković, Šutej and Vlado Kovačević, who were considering moving to South Africa. ${ }^{187}$ However, some of the CPP members decided to go to Argentina, so Reberski and his family moved to that country at the end of March 1947, ${ }^{188}$ and by the summer of 1947, Torbar and his sons had done the same. ${ }^{189}$ Vučković went to Belgium in the middle of 1947. With their departure, the Roman CPP committee also ceased to exist, but regardless, the CPP members continued to be active in the Fermo and Bagnoli camps, while Pernar focused on working in the Yugoslav Welfare Society. ${ }^{190}$ During the spring of 1947, Rector Mađerec closed the "Zagreb canteen" prompted by the arrests of Croatian emigrants in front of the Institute and after Ustasha emigrants were attacked in the Italian newspaper "Unita" and the Institute was qualified as their center. ${ }^{191}$ Pernar and his wife travelled from Italy to the United States in 1948, although according to some sources, Maček's wish was to move to Argentina first, which Pernar refused. ${ }^{192}$

\section{Conclusion}

The activities of the CPP in Italy from 1945 to 1947 were reduced to the activities of prominent CPP officials, who received instructions for their political work from Paris from President Maček, with whom they were in direct contact all along. The aggravating circumstance of the action was the mutual division resulting from their different activities during the war in the NDH and their political views on the current situation at the time and the relationship with other emigrant groups. Regardless of the division, everyone worked to help Croatian refugees. The membership of as many refugees as possible

\footnotetext{
186 HR-HDA-1561, 10.13/3, "Politička aktivnost naše emigracije”, December 24, 1946, pp. 2930.; HR-HDA-1561, 10.13/3, "Stanje kod mačekovaca", January 24, 1947, pp. 54-55.

187 HR-HDA-1561, 10.13/3, “Stanje kod mačekovaca”, January 24, 1947, pp. 54-55.

188 HR-HDA-1561, 10.13/3, “Političke grupacije među emigracijom”, April 16, 1947, p. 57.

189 HR-HDA-1561, 10.13/3, “Aktivnost HSS-a u inostranstvu”, 1946., p. 48.

190 Ibidem.

191 HR-HDA-1561, 10.1/5, “Aktivnost jugoslavenske emigracije”, March 30, 1948, p. 9.; Lendić, Božji Kotači, pp. 16-19.

192 Petrić, "prilozi za biografiju Ivana Pernara (1889.-1967.)", p. 203.
} 
was important for the CPP because of its strength in the face of international factors, and on the other hand, it was easier for refugees to resolve their refugee status and relocation to overseas countries through the CPP. The first time of emigration among the CPP members was a glimmer of hope for a quick return to the homeland with the help of Western democratic factors and even an agreement with Tito, but as time went on everyone became aware that long-term emigration awaited them. Consequently, most of them moved to South American countries by mid-1947, while the last to move from Italy was Ivan Pernar to the United States in 1948.

\section{Bibliography}

\section{Archival sources and newspapers:}

Hrvatski državni arhiv (HDA) [Croatian State Archives], fond [Record Group] 1561, Služba državne sigurnosti Ministarstva unutrašnjih poslova Socijalističke Republike Hrvatske (SDS RSUP SRH) [State Security Service of the Ministry of the Interior of the Socialist Republic of Croatia] (Record Group's Signature: HR-HDA-1561)

Hrvatski glas (Winnipeg, Canada)

\section{WEB sources:}

CIA Documents, www.cia.gov/readingroom/

\section{Literature:}

Bauer, Ernest. Život je kratak san [Life is a short dream]. Barcelona-Munich: Knjižnica Hrvatske revije, 1986.

Boban, Branka. "Vladko Maček u emigraciji - od izlaska iz zemlje do odlaska u SAD" ["Vladko Maček in exile - from leaving the country to going to the USA"], Radovi Zavoda za hrvatsku povijest Filozofskog fakulteta Sveučilišta u Zagrebu 39 (2007), No. 1: 243- 258.

Crljen, Danijel. Otvoreno pismo dru Vladku Mačeku, predsjedniku Hrvatske seljačke stranke [An open letter to Dr. Vladko Maček, President of the Croatian Peasant Party]. Buenos Aires: writer's edition, 1948.

Geiger, Vladimir, Leček, Suzana. 'Živan Kuveždić - ministar na saslušanju (Iskaz Živana Kuveždića UDB-i NR Hrvatske u rujnu 1948. o boravku 
u zarobljeničkim logorima i zatvorima u Italiji i Njemačkoj od svibnja 1945. do kolovoza 1948.)” [““'Živan Kuveždić - Minister at the hearing (Testimony of Živan Kuveždić to the Secret Service of the People's Republic of Croatia in September 1948 about his stay in prison camps and prisons in Italy and Germany from May 1945 to August 1948)"], Politički zatvorenik 22 (2012), No. 241: 34-39.

Jandrić, Berislav. "Saveznički izbjeglički logori počeci otpora hrvatske političke emigracije komunističkom režimu u domovini/logor Fermo/" ["Allied refugee camps beginnings of resistance of Croatian political diaspora to the communist regime in the homeland / Fermo camp"], in: 1945. - razdjelnica hrvatske povijesti: Zbornik radova sa znanstvenog skupa održanog u Hrvatskom institutu za povijest od 5. do 6. svibnja 2005., ed. Nada Kisić Kolanović, Mario Jareb and Katarina Spehnjak. Zagreb: Hrvatski institut za povijest, 2006., pp. 305-322.

Jareb, Jere. "Dr. Krunoslav Draganović o svojem radu u Italiji, od rujna 1943. do ožujka 1946." [Dr. Krunoslav Draganović on his work in Italy, from September 1943 to March 1946], Hrvatska revija (München-Barcelona), 34 (1984), No. 4: 589 - 611.

Jareb, Jere. Zlato i novac NDH izneseni u inozemstvo 1944. i 1945. [Gold and money of the Independent State of Croatia exported abroad in 1944 and 1945]. Zagreb: Hrvatski institut za povijest - Dom i svijet, 1997.

Jelić-Butić, Fikreta. Hrvatska seljačka stranka [Croatian Peasant Party]. Zagreb: Globus, 1983.

Jure Krišto, “Fra Dominik Mandić i hrvatske izbjeglice 1943. - 1953.” [“Fr. Dominik Mandić and Croatian refugees 1943-1953“], in: Dr. fra Dominik Mandić (1889. - 1973.). Zbornik radova sa znanstvenog simpozija održanog u prigodi 40. obljetnice njegove smrti (Mostar - Široki Brijeg, October 23 and 24, 2013), ed. Fra Ante Marić. Mostar - Zagreb: Hercegovačka franjevačka provincija Uznesenja BDM, Franjevačka knjižnica Mostar and Hrvatski institut za povijest, 2014., pp. 686-720.

Kapitanović, Vicko. "Fra Karlo Balić i hrvatsko iseljeništvo" ["Fr. Karlo Balić and the Croatian Diaspora"], in: Aktualnost predaje: Zbornik radova međunarodnoga znanstvenog skupa prigodom 100. obljetnice rođenja fra Karla Balića, Split, 6. XI. 1999., ed. Marko Babić. Makarska: Služba Božja, 2003., pp. 265-311.

Katalinić, Kazimir. Od poraza do pobjede [From defeat to victory], vol. 1. Zagreb: Naklada Trpimir 2017.

Krišto, Jure. "Zagrebačka Židovka Heda Stern u lovu na Pavelića” ["Zagreb Jew Heda Stern in the hunt for Pavelić"], Časopis za suvremenu povijest 42 (2010), No. 1: 55-72. 
Krizman, Bogdan. Pavelić u bjekstvu [Pavelić on the run]. Zagreb: Globus, 1986.

Lendić, Ivo. Božji kotači [God's wheels]. Split: Laus d.o.o., 2001.

Lukinović, Andrej. "Bratovština svetog Jeronima za pomoć hrvatskim izbjeglicama" ["Brotherhood of St. Jerome to help Croatian refugees"], in: Papinski hrvatski zavod svetog Jeronima (1901-2001). Zbornik u prigodi stoljetnice Papinskoga hrvatskog zavoda svetog Jeronima, ed. Jure Bogdan. Rome, Italy: Papinski hrvatski zavod svetog Jeronima i Glas Koncila, 2001., pp. 771-841.

Maček, Andrej and Škrabe, Nino (eds). Maček izbliza [Maček up close]. Zagreb: Disput, 1999.

Maček, Vladko. Memoari [Memoirs]. Zagreb: Hrvatska seljačka stranka, 1992.

Marica Karakaš Obradov, “'Depoi špijuna i terorista’. Saveznički logori za 'raseljene osobe' u Italiji, Austriji i Njemačkoj" ["'Depots of spies and terrorists'. Allied camps for 'displaced persons' in Italy, Austria and Germany"], in: 1945. - Kraj ili novi početak. Tematski zbornik radova, ed. Zoran Janjetović. Beograd: Insitut za noviju istoriju Srbije, 2016., pp. 309-337.

Milanović, Božo. Istra u dvadesetom stoljeću [Istria in the twentieth century], vol 2. Pazin: "Josip Turčinović" d.o.o., 1996.

Mostovac, Milivoj. "Idejno izbjeglištvo: Rim 1945-47" ["Ideologically exile": Rome 1945-47], in: Hrvatska revija - Jubilarni zbornik 1951 - 1975, ed. Vinko Nikolić. München-Barcelona: Knjižnica Hrvatske revije , 1976., pp. 372-379.

Nikolić, Vinko. Tragedija se dogodila u svibnju [The Tragedy occurred in May] vol. 2. Zagreb: Školske novine, 1995

Pešelj, Branko M. "S predsjednikom Mačkom u emigraciju" ["With President Maček in Exile”], Hrvatska revija 20 (1970), No. 4: 757-811.

Petrić, Hrvoje. "Prilozi za biografiju hrvatskog političara Josipa Torbara” ["Contributions to the biography of Croatian politician Josip Torbar"], Zbornik Janković 3 (2018), No. 3: 182-197.

Petrić, Hrvoje. "Prilozi za biografiju Ivana Pernara (1889.-1967.)” [“Contributions to the biography of Ivan Pernar (1889.-1967.)"], Zbornik Janković 2 (2017), No. 2: 167-206.

Radelić, Zdenko. Hrvatska seljačka stranka 1941. - 1950. [Croatian Peasant Party 1941. - 1950.]. Zagreb: Hrvatski institut za povijest, 1996.

Radelić, Zdenko. Križari: Gerila u Hrvatskoj 1945. - 1950. [Crusaders: Guerrillas in Croatia 1945-1950]. Zagreb: Alfa d.d. and Hrvatski institut za povijest, 2011. 
Robionek, Bernd. Croatian Political Refugees and the Western Allies: A documented History. Berlin: Osteuropa - Zentrum Berlin, 2010.

Rojnica, Ivo. Susreti i doživljaji [Encounters and Experiences]. Zagreb: DoNeHa, 1994.

Schmidt, Amy. "Vladko Maček i Hrvatska seljačka stranka: Prizori iz izbjeglištva" ["Vladko Maček and The Croatian Peasant Party: Scenes from Exile”], Časopis za suvremenu povijest 37 (2005), No. 3: 407-422.

Tepeš, Ivan. Hrvatska politička emigracija - HSS [Croatian political diaspora - CPP]. Zagreb: AGM d.o.o., 2021. 